\title{
TEMPLOMÉPÍTÉSZET A SZOCIALIZMUSBAN
}

\author{
SZERKEZET, FORMA ÉS SZAKRÁLIS TARTALOM VISZONYA \\ AZ 1970-1980-AS ÉVEK MAGYARORSZÁGI RÓMAI \\ KATOLIKUS TEMPLOMÉPÍTÉSZETÉBEN
}

\author{
URBÁN ERZSÉBET \\ Abszolvált PhD-hallgató. BME Építésztörténeti és Múemléki Tanszék, \\ 1111 Budapest, Mủegyetem rkp. 3. K II. 82. Tel.: (+36-30) 272-6427. E-mail: urban.e.bme@gmail.com
}

\begin{abstract}
A II. világháborút követő politikai hatalomváltás utáni egyháztalanítás következményeként a magyarországi keresztény egyházak korábbi intenzív templomépítési tevékenysége alapvetően megtorpant. A két világháború közötti gazdag emlékanyag építészeti stílusának és formálásmódjának fokozatosan enyhülő hatása még majd két évtizeden át nyomon követhető, ám az 1960-as évek elejétől új formakísérletek kezdődtek. A katolikus egyház templomépítészetében a II. vatikáni zsinat impulzusának köszönhetően az 1970-es évektől kiszélesedett a stíluspluralizmus, és a korábbi hagyományos anyaghasználat mellett korábban nem alkalmazott épületszerkezetek és építőanyagok is megjelentek (gyakran iparias, már-már profán hatását keltve a szakrális térnek). Részben az alkotói munkásságoknak köszönhetően az újító megoldások a protestáns egyházak építészetében is teret nyertek. A tanulmány a szerkezetiség megjelenése és annak vizuális-esztétikai hangsúlya mentén vizsgálja az emlékeket, de nem a tendenciák megállapítására, hanem az egyes alkotói módszerek értékelésére helyezi a hangsúlyt. Az áttekintés a korábbi szakirodalomban számon tartott emlékanyaghoz képest jelentősen nagyobb számú további épületállományt vesz figyelembe, melyek többsége építőmüvészeti szempontból ugyan nem bír kiemelkedő jelentőséggel, mégis szociológiai-egyháztörténeti szempontból fontos a számszerüségük és az építésük ténye. A példák sorából kitünik, hogy a korszak első harmadában épült templomoknál még erősen a hagyományos hossztengelyes elrendezés dominált a megszokott téglafalazatos és fa ácsszerkezettel készült tetővel, míg később gyakoribbá vált a vasbeton vázas és vázkitöltő falazatos, illetve vasbeton födémmel készült, szabadon formált szerkezeti rendszerek alkalmazása. A vizsgált periódus utolsó időszakában a posztmodern terjedésével, valamint a historizáló elemek újrafelfedezésével ismét előtérbe kerültek a hagyományos építési anyagok és szerkezetek. A tanulmány nem időrend szerint sorolja a kiválasztott épületeket, hanem az építész alkotók szerint tagol, és a szerkezet belső térre gyakorolt hatása alapján elemez.
\end{abstract}

Kulcsszavak: római katolikus templomépítészet, II. vatikáni zsinat, liturgikus reform, épületszerkezetek, építészeti forma és szakrális tartalom

\section{ELÖSZÓ}

A II. világháborút követő politikai változások hatása az egyházak életére és a magyarországi templomépítészet területére társadalomtudományi oldalról már feldolgozott téma, az építészettörténet-írás által viszont csak részleteiben tárgyalt. E korszakot nagy vonalakban áttekintö, összefoglaló mü Rév Ilona 1987-ben kiadott Templomépítészetünk ma címü könyve (Rév 1987), valamint az ezt követő 1980-as évek templomépítészetével mint prekortárs formákkal foglalkozó, Wesselényi-Garay 
Andor által szerkesztett Mindenség modellje - Kortárs magyar templomépitészet címü kötet (Wesselényi-Garay 2010). Rév Ilona munkája az egyes templomok építészeti interpretációját tekintve nem törekszik tágabb kontextusra, és a rövid leírásokon túl átfogóbban nem is reflektál más templomokra. Ezzel szemben a retrospektív szemléletü Mindenség modellje kötet már a rendszerváltás utáni épületekre koncentrál, és inkább csak előzményként értékeli a szocializmus utolsó harmadában épült templomokat. Előbbi tehát a korszak visszafogott önértékelésének, utóbbi pedig a 21. századi templomépítészet hazai előképei feltérképezésének tekinthető. Lényeges kutatási forrás még az 1980-ban megrendezett templomépítészeti kiállítás iratanyaga, valamint a hozzá kapcsolódó kiállítási katalógus. ${ }^{1}$ További, rövidebb, néhány épületet bemutató vagy esetleg egy-egy évtizedet áttekintő tudományos cikkek az 1990-es évek közepétől kezdődően egyre nagyobb számban jelentek meg (akár tervezői életmü révén, akár formai-stíluskritikai hasonlóságokhoz kapcsolódó tanulmányok formájában).

A szocializmus korszakában komoly társadalmi, kisközösségi összefogás árán épített templomok pontosan tükrözik, hogy amikor a mérnöki tervezés jelentős akadályokba és korlátozásokba ütközik, milyen praktikus, ám szellemes építészeti válaszokat kell adniuk a tervezőknek, hogy igazán egyedülállót alkothassanak. A szabadon fejlődő szakrális építészet cezúrája után már ezek a szükségmegoldásokkal teli építkezések is hatalmas előrelépésnek számítottak. Az 1960-as évek végétől új periódus kezdődött a szakrális építészetben, mely a stílusjegyek alapján a rendszerváltásig tartott: megjelent templomépítészetünkben is az ipari anyagok és szerkezeti rendszerek alkalmazása. Ezen építészeti szemléletváltásnak a liturgikus térformálásra és a szakrális építészeti, esztétikai minőségre gyakorolt hatása a szerkezet-forma-szakralitás összefüggésében eddig részletesebben nem vizsgált kérdéskör.

\section{EGYHÁZ A POLITIKA ÁRNYÉKÁBAN}

A II. világháborút követően Magyarország szovjetizálásával, az egypártrendszer kialakulásával és a társadalom átrétegződésével párhuzamosan az oktatás, a tudomány és a kultúra is fokozatosan államosításra került. A Rákosi-diktatúra pártállamiságának kemény megszorításait követően azonban a Kádár-korszakra általánosságban már inkább az ,, aki nincs ellenünk, az velünk van ” felfogás volt jellemzö. ${ }^{2}$ Ennek megfelelően alakultak az egyházakkal kapcsolatos politikai intézkedések fázisai is: a kezdeti időszakban a teljes represszió sújtotta az egyházakat, majd az állami kontroll fokozatosan egy kompromisszumkészebb, társutas együttmüködés irányába alakult.

A korszak egyházpolitikai eseményei az 1945-öt követő hazai templomépítészet fejlődési lehetőségeit is alapjaiban határozták meg. ${ }^{3}$ Kezdetben a politikai vezetés az

\footnotetext{
${ }^{1}$ Neue Kirchen in Ungarn 1945-1980. Keresztény Múzeum, Esztergom 1980.

${ }^{2}$ A korszak átfogó történeti összefoglalóját adja: Romsics 2010.

${ }^{3}$ Az egyház-állam II. világháború utáni viszonyának részletes ismertetését adja: Gergely 1985.
} 
egyszerübb ellenőrizhetőség érdekében közjogilag teljesen szétválasztotta az egyházat és az államot, ${ }^{4}$ majd politikai eszközökkel visszaszorították a korábbi erős vallási hagyományokat és szükre szabták az egyházak múködési területét. Nemcsak a gondolati szabadság és szellemi útmutatás kérdésében függött az egyház az államtól, hanem az anyagi támogatás következtében a helyreállítási, építési tevékenység területén is. ${ }^{5}$

A nyílt egyháztalanítás évei után egy kiszámíthatatlanabb időszak következett, amikor a tiltás-megengedés politikájával kezelte az állam az egyházakat: az egyházak idővel modus vivendire törekedtek, az állam pedig a korábbi nyílt konfrontáció helyett leginkább anyagi megszorításokkal korlátozta a hitélet szabad gyakorlását. A változó politikai módszerek, a szélsőséges személyi atrocitások és az engedékenyebb békepapi mozgalom támogatása között állandósulni látszó bizonytalanság jellemezte az állam és egyház viszonyát. ${ }^{6} \mathrm{~A}$ Vatikán új keleti politikájának köszönhetően, ${ }^{7}$ valamint a szocialista államvezetés megváltozott szemlélete következtében a magyar főpapok kimehettek a II. vatikáni zsinat üléseire, illetve az ad limina látogatásokra. De ezek is kizárólag úgy valósulhattak meg, hogy a delegáció politikai szempontok szerint megválogatott tagokból állt, s önálló nézőpont képviselete nélkül, csak pontosan körülhatárolt információkat közvetíthettek. A püspökök számára az Állami Egyházügyi Hivatal $(=\text { ÁEH })^{8}$ által összeállított adatok ugyan rendelkezésre álltak az egyházmegyéik vallási életére vonatkozóan, ám ezek hitelességéről, illetve ellentmondásairól bizonyosságuk nem volt.

A nemzetközi elszigeteltségből kitörni szándékozó szocialista államvezetés ugyanakkor látványos egyezmény megkötését szorgalmazta: az 1964-es részleges meg-

${ }^{4}$ Köbel Szilvia alkotmányjogász az 1945-1948 közötti időszakot a „békés elválasztás” éveinek azonosítja, míg az 1949-1989 közötti periódust egységesen az „ellenséges elválasztás” eszközeivel jellemzi. Köbel 2005. 157.

${ }^{5} \mathrm{Az}$ 1945. évi földreform és az azt követő anyagi megszorítások tényleges jelentősége csak évekkel később vált valóban érzékelhetővé. Ennek elemzését adja: Doromby 1975. 232. Az egyházakat sújtó földreform jogi-gazdasági jelentőségét elemzi: Szigeti 1973.

${ }^{6}$ 1980-ra megszokottá vált a békepapi mozgalom tevékenysége, az állam és egyház közötti párbeszéd azonban továbbra sem volt nyitott. Részletesen: Bíró 1980. A békepapi teológia kidolgozására tett kísérletről: Albertini és mtsai 1977.

${ }^{7}$ VI. Pál pápa a szocialista államokkal történő aktív kapcsolatfelvételének bizonyságai: ,az 1964-ben Magyarországgal, 1955-ben és 1970-ben Jugoszláviával kötött megállapodás, Podgornij szovjet államfö (1967), Maurer román miniszterelnök (1968) és Tito jugoszláv államelnök vatikáni látogatása, apostoli adminisztrátorok (1967), majd megyéspüspökök (1972) kinevezése Nyugat-Lengyelországban, püspökök kinevezése Csehszlovákiában (1973) és apostoli adminisztrátorok kinevezése a Német Demokratikus Köztársaságban (1973). ” Adriányi 2001b. 207.

${ }^{8} \mathrm{Az}$ ÁEH 1951. május 18-án lett létrehozva kezdetben csak az egyházak felügyeletére, ám idővel a szervezet az anyagi korlátozások útján is felügyelte az építkezések és helyreállítások menetét. A működés első szakaszában a vallásosság teljes felszámolását próbálta elősegíteni, melyet a hitoktatás és a vallási élet korlátozásával igyekeztek gyorsítani. Az ÁEH müködéséröl: Köpeczi 2004. A hivatal megalakulása után többször átszervezésre került. Az 1961-es újjászervezést követően nagyobb változtatások már nem történtek a müködési módszert illetően. Ekkor a következő egységek voltak a szervezetben a Titkárság mellett: Katolikus Főosztály, Protestáns és más Felekezetek Főosztálya, Pénzügyi és Igazgatási Osztály. Az ÁEH megszünéséröl csak az 1989. évi 14. sz. törvény rendelkezett. Az ÁEH szervezeti felépítéséről: Kisasszondy 2005. 7-11. 
állapodás az Apostoli Szentszék és a Magyar Népköztársaság között ${ }^{9}$ formálisan rendezett néhány vitás kérdést (egyik ilyen pont a hitoktatás lehetősége volt). ${ }^{10} \mathrm{Az}$ egyezmény után továbbra sem javult az ÁEH-megbízottak szoros ellenőrzése a püspöki rezidenciákban: külön irodákban ugyan, de a megyeszékhelyeken, illetve a püspöki székvárosokban zavartalanul tovább múködtek a megbízottak. ${ }^{11}$ A Politikai Bizottság 1968. március 4-i párthatározata még mindig a katolikus egyházat tartotta a ,legbonyolultabb és legtöbb problémát” jelentő felekezetnek, ám azáltal, hogy a püspöki karba lojális személyek kerültek, a békepapi mozgalom is hatékonyabbá vált. ${ }^{12}$

Az 1970-es évek második felétől az ÁEH igazodott a Magyar Szocialista Munkáspárt által kijelölt enyhülő egyházpolitikához. ${ }^{13} \mathrm{Az}$ ÁEH adminisztratív feladata nőtt, tényleges aktív tevékenysége viszont csökkent. A valóságban azonban a családpasztoráció nehezen ment, a házasságkötések jelentősebb része végződött válással, $\mathrm{s}$ a marxista nevelés egy teljes generációt fosztott meg az egyházi értékek megismerésének lehetőségétől. ${ }^{14} \mathrm{Az}$ egyházi intézmények nyomon követése és ellenörzése mellett a külföldi nyitás révén az egyházi vezetők nemzetközi kapcsolatainak figyelemmel kísérésével is foglalkoztak. A korszakban 1973-ban, majd 1983-ban volt nagyobb átfogó revíziója az egyháznak, mely az addig kidolgozott állami egyházpolitikai elvek megvalósulását értékelte..$^{15}$

Az 1956-os forradalom idején határozott politikai állásfoglalást tevő, majd a forradalom vérbefojtása után az Amerikai Egyesült Államok budapesti nagykövetségén menedéket lelő Mindszenty József bíboros személyes jelenléte állandó feszültséget eredményezett az állam és egyház viszonyában. A körülményes tárgyalások eredményeképp a bíboros végül elhagyta az országot. ${ }^{16} \mathrm{~A}$ Vatikánban azonban nem volt maradása, így kérésére Bécsbe költözhetett. ${ }^{17} \mathrm{~A} 80$. életévébe lépő bíboros nyugalmazásával a Szentszék 1974. február 5-én formálisan üresnek nyilvánította az esztergomi érseki széket, ${ }^{18}$ és Lékai László c. püspököt apostoli kormányzónak nevezte ki.

\footnotetext{
${ }^{9}$ A megállapodást az 1990. február 9-én aláírt egyezmény helyezte hatályon kívül, mindaddig érvényben volt. A részleges megegyezés három évtizeddel későbbi újraértékelése egyházi oldalról: Cserháti 1980.

${ }^{10} \mathrm{Az}$ időközben már részlegesen megvalósuló vallásszabadság ellenére az ateista jellegü közoktatás eredményeképp az elvallástalanodás kiszélesedett, és ezzel párhuzamosan az egyházak papságának létszáma is majd felére-harmadára esett vissza. Balog-Gergely 2005. 79. A fiatalok lelki gondozásával való tevékenykedés okán ,államellenes összeesküvés” vádjával sorozatos, tömeges letartóztatások történtek (1965, 1966, 1967, 1970, 1972). A részmegállapodás eredményeiről és eredménytelenségeiről: Adriányi 2001a. 65-70.

${ }^{11}$ Adriányi 2001a. 61.

${ }^{12}$ Köbel 2005. 137-138.

${ }^{13}$ 1973-tól leginkább csak az információs és dokumentációs feladatkör maradt. Az ÁEH 1951-1989 közötti belső müködéséröl és tevékenységéröl: Köbel 2005. 60-91.

${ }^{14}$ Bozsóky-Lukács 2005. 101-104.

${ }^{15}$ A két határozat részletes vizsgálata: Köbel 2005. 139-142.

${ }^{16}$ A tárgyalások előzményeiről, menetéről és problematikájáról részletesen: Adriányi 2001a. 88-119.

${ }^{17}$ Mindszenty bíboros 1973-ban megjelentette Emlékirataim címü munkáját, majd halála elött még több utazást tett a világban, hogy felkeresse és erősítse a külföldön élő magyar közösségeket.

${ }^{18}$ Somorjai 2007.
} 
Mindszenty bíboros rövidesen bekövetkező halálával az érseki szék ténylegesen megüresedett, így 1976 februárjában VI. Pál Lékai püspököt kinevezte esztergomi érsekké. ${ }^{19}$ Mivel az állami vezetés könnyen befolyásolta a pozícióba kerülö püspökök és elöljárók személyét, így ekkoriban már e vezetők megfelelő hozzáállásának motiválása volt az állam célja: „,Ezeket az új helyzetbe került egyházi vezetöket »be kell programozni«, hogy úgy értelmezzék a feladatokat, ami nekünk optimálisan a legjobb." 20

1977-ben VI. Pál pápa magánkihallgatáson fogadta Kádár Jánost, az MSZMP első titkárát. Ebben az évben Miklós Imre államtitkár - az ÁEH akkori elnöke - állami szempontból már elfogadhatónak ítélte meg az egyházi vezetők tevékenységét, mert politikai elkötelezettségük ,elérkezett ahhoz a szinthez, amely a szocializmus érdekében elegendo" ${ }^{21}$ A templomi hitoktatás ellenörzésének joga így visszakerülhetett a püspöki kar felügyelete alá, s ezután már elsősorban csak az anyagi megszorítások befolyásolták az egyházmegyék működését. Az ún. kis lépések politikájával a kevésbé jelentős kérdésekben folyamatos megállapodások születtek a magyarországi Római Katolikus Egyház és a magyar állam között. ${ }^{22}$

Míg az 1950-es években az egyház müködésképtelenné tétele volt a cél, addig az 1980-as évek kezdetétől a tárgyalásos együttműködés került előtérbe ${ }^{23}$ (de a politikai hatalom részéről mindig szem elött tartva, hogy végső soron az állam jöjjön ki kedvezőbben az alkukból). ${ }^{24}$ Nagyobb szerep jutott az egyházi vezetők egyházon belüli ügyintézésének, mellyel a szocialista vezetés próbálta saját mintájára formálni az egyházi hierarchián belüli döntéshozatali és ellenőrzési rendszereket. ${ }^{25}$ Még 1987 után is hangsúlyozta az ÁEH, hogy továbbra is fontosnak tartják a korábbi módszerekkel összhangban az egyházi társadalom kettéválasztását (a kölcsönös megállapodásokon alapuló viszonyt elutasító személyek és az államvezetéssel együttmüködő egyházi vezetők elidegenítésével). Az 1970-1980-as évek időszakára általánosan

${ }^{19}$ Lékai László bíboros munkájának lehetőségeiről és korlátairól: Bozsóky-Lukács 2005. 112-115.

${ }^{20}$ MOL-XIX-A-21-e-0010-1/1975.

${ }^{21}$ MOL-XIX-A-21-d-0010-4/1977. Elöadás és konzultáció az MSZMP Politikai Bizottsága 1973. december 4-ei határozata végrehajtásának tapasztalatai alapján a további feladatokról. 1977. február 22. Az anyagot részletesen elemzi: Köbel 2005. 159.

${ }^{22} \mathrm{Az}$ állam ugyan toleránsabbá vált az egyházi tevékenységgel szemben, ám néhány kritikus érdekütközési pont még fennmaradt. Az egyik ilyen fontos kérdés a fiatalok nevelése, az ifjúsággal való foglalkozás volt, melyet az állam és az egyház is saját súlyponti feladatának tekintett. 1978 öszén a Budapesti Hittudományi Akadémián először indult hároméves teológiai levelező tanfolyam. 1979-ben Paskai László veszprémi püspök (1979. március 31-től) és Bagi István c. püspök és esztergomi segédpüspök felesküdtek az Alkotmányra. A korszak egyházpolitikai és társadalmi eseményeiről részletesen: Balogh-Gergely 2005. 79-84.

${ }^{23}$ Az együttmüködésben kiemelkedő jelentősége volt II. János Pál pápának, akit 1978-ban választottak pápává. A II. világháború után a Magyar Népköztársaság Kormánya és a Magyar Katolikus Püspöki Kar között létrejött első megállapodást (1950. augusztus 30-án jött létre), illetve az azt követő viszonyt értékeli 30 év távlatából: Lékai 1980 és Miklós 1980.

${ }^{24}$ A tényleges viszony Kádár János 1980-as egyik kongresszusi beszédéből érzékelhető. Közli: Vigilia 1980.

${ }^{25}$ Köbel 2005. 158-159. 
jellemző volt, hogy a tettre kész egyházi vezetőknek meg volt kötve a kezük, és be kellett látniuk, hogy alapvetően csak kis lépésekben érhetnek el eredményeket. ${ }^{26}$

\section{AZ 1945 UTÁNI ÉVEK HAZAI TEMPLOMÉPÍTÉSZETÉNEK LEHETÖSÉGEI ÉS KORLÁTAI}

A II. világháborút követő húsz évben az építési tevékenység jelentős hányadát a romba dőlt és súlyosan megrongálódott épületek helyreállítása adta. Ezzel párhuzamosan a bővülő lakó- és közösségi funkciók mielőbbi, mennyiségi jellegű kielégítésére törekedett az építőipar, így a munkaerő és az építőanyag hiánya miatt a minőség gyakran háttérbe szorult. ${ }^{27}$ Míg a két világháború közötti időszak erős társadalmi beágyazottsággal bíró egyházai a Gerevich Tibor vezetésével létrejött és kiteljesedett római iskola haladó gondolkodású tervezőinek alkotásai révén progresszív fejlődést tudtak mutatni a templomépítészet terén - s így nemzetközi szinten is létrejöhettek kiemelkedő minőségű és művészi értékű alkotások -, addig a II. világháborút követő első évtizedekben ennek csak visszafogottabb és egyre halványuló színvonalát sikerült már megvalósítani. ${ }^{28}$ Az 1945 utáni templomépítészet első, újjáépítésekkel és új építésekkel is teli szakaszát ${ }^{29}$ az 1960-as évek végétől a nyugat-európai mintákat ismét figyelemmel kísérő, újfajta építészeti kifejezésmódot kereső, kísérletezőbb formálásmód követte. ${ }^{30}$ A II. világháború előtti modern építészeti formaképzés az 1960-as évek elejére (nagyjából az Árkay-életmű lezárulásával) ${ }^{31}$ a templomépítészetben eltünt.

Az 1950-1960-as évek tömeges lakásépítési programjai ${ }^{32}$ és iparfejlesztései után az 1970-es évektől ismét előtérbe került az építészetben az épület mint konceptuális

\footnotetext{
${ }^{26} \mathrm{Az}$ egyház mégis tudta, hogy elengedhetetlen a társadalmi megújulásra koncentrálnia. Ezt a törekvést szimbolizálta Lékai László bíboros latinból vett jelmondata is: Arbor succisa virescit, miszerint ,, a megnyesett fa kizöldül”.

${ }^{27}$ Merényi 1970. 103.

${ }^{28}$ A két világháború közötti modern templomépítészetet átfogóan elemzi: Hajós-Baku 2018. - Az 19001950 közötti európai templomépítészetet áttekintő Stock-kötetbe a Rimanóczy Gyula által tervezett pasaréti római katolikus templom, valamint Árkay Aladár és Árkay Bertalan városmajori Jézus Szíve temploma került be a magyarországi épületek közül. Stock 2006. 22-23.

${ }^{29} \mathrm{Az}$ 1945-öt követő néhány évben még a félbehagyott templomok befejezési munkái, valamint az elpusztult templomok helyén történő új építkezések voltak jellemzőek, azután az egyre szembetűnőbb gyors társadalmi és politikai változások hatására viszonylag sok helyen, rövid idő alatt új templomépítések sora indult meg. Látva a súlyosbodó körülményeket, ezen építkezéseknek többsége egy-két éven belül befejeződött, s az „építési hullám” nagyjából az 1949-es évvel zárult. Vukoszávlyev-Urbán 2016.

${ }^{30}$ Merényi 1970. 121-127.

${ }^{31}$ Árkay Bertalan II. világháború utáni templomépítészeti életművét bemutatja: Urbán-Vukoszávlyev 2016 .

${ }^{32}$ A tömeges lakásépítés társadalomra gyakorolt hatását az egyházi lapok is elemezték. 1980-ban a Magyar Nemzeti Galéria által rendezett Forma és struktúra - konstruktivizmus a modern finn épitészetben, képzömüvészetben és formatervezésben címü kiállítás apropóján érzékelhető volt az északi, élhető struktúrájú lakótelepek és a magyarországi társaik közötti kontraszt. Andrási 1980. 863.
} 
mü. ${ }^{33}$ A korszerü anyagok alkalmazása mellett a low-tech építészet és az organikus mozgalom is kezdett erősödni, illetve az 1970-1980-as évek fordulóján megjelent a posztmodern, melynek hatása még a rendszerváltás után is érvényesült. Az építőipar államosítása és a tervezőintézetek létrehozása mellett a Magyar Építőmüvészek Szövetsége az építészek társadalmi szerepvállalását igyekezett összefogni, továbbá jelentős szerepet vállalt a korszak építészeti arculatának kialakításában. ${ }^{34}$

A tervszerü urbanisztikai fejlesztések ${ }^{35}$ az összes jellemző középület elhelyezését biztosították a városszöveten belül, ${ }^{36}$ azonban a szocialista ideológiával szemben álló templomok építését továbbra sem támogatták. ${ }^{37}$ Míg a kiegyensúlyozott időkben a templom mint épület elsősorban a tiszteletadás tere, addig a vészterhes, bizonytalan korokban a templom menedék, mely hitet és kitartást ad a mindennapok nehézségeinek elfogadásához. A templomépítészetben tehát különösen meghatározó a hely, a környezeti kontextus. Míg a történelem békés periódusaiban a templom magaslaton (illetve a környező épületekhez képest önmaga magasságával is) hirdette Isten dicső létét, addig a szocializmus alatt jellemzően a városi szöveten belül legtöbbször periferikus helyre szorult, de ha a közbenjárások eredményeképp központi telekre is épülhetett egy templom, jellemzően csak visszafogott formát kaphatott. ${ }^{38}$

\section{SZELLEMI ÉS FORMAI MEGÚJULÁS A SZAKRÁLIS ÉPÍTÉSZETBEN}

A II. világháború traumája - a keleti blokk országaiban bekövetkező ateista államberendezkedés okozta drasztikus változások okán pedig kiváltképp - után időszerủvé vált a vallási-lelki megújulás. A 20. század derekán már tapasztalhatóan igény jelentkezett a szakrális építészetben is a lényegi változások iránt, és ennek az újrakezdésnek egy erős motiváló lendületet adott a II. vatikáni zsinat, mely megváltoztatta a templom közösségi tartalmát. ${ }^{39}$ Ennek látványos formai megjelenése volt az egyén és közösség részvétele az istentiszteletben (participacio actuosa), valamint szimbolikus

${ }^{33} \mathrm{Az}$ 1970-es évek hazai építészetének két irányba induló „karakterkereséséről”: Simon 2001.

${ }^{34}$ Ferkai 1985. A II. világháború utáni hazai építészet áttekintését adja: Ferkai 1998.

${ }^{35} \mathrm{Az}$ élhető, emberi léptékű városi szövet alakításához szükséges, hogy a különböző szakemberek saját szakterületük vonatkozásában megvizsgálják a városépítészet kérdéseit. J. Comblain La théologie de la ville címü, 1968-as könyvében vallás és egyház szerepét elemzi a modern városban. E munkát, illetve urbanizmus és teológia kapcsolatát vizsgálja: Bangó 1970.

${ }^{36}$ Kleineisel 1986.

${ }^{37}$ A magyar építészetet 1967-ig bemutató, Merényi Ferenc által összeállított áttekintő kötet a II. világháború utáni időszakból mindössze négy egyházi-szakrális épületet szerepeltet (Hollóháza és Cserépváralja római katolikus templomai, a szegedi belvárosi temető ravatalozója, valamint a kecskeméti temető bejárati épülete). Merényi 1970. 139. Ezzel szemben az 1945-1967 közötti időszakban lényegesen gazdagabb templomépítészeti örökség jött létre, erről részletesen: Vukoszávlyev-Urbán 2016.

${ }^{38} \mathrm{Az}$ 1960-1970-es évek templomépítészetét múvészettörténész megközelítésből vizsgálja: Lantos 2018.

${ }^{39}$ Török-Török 2016. 13. 
tartalmával a versus populum mensa-oltár megjelenése..$^{40}$ A zsinati reformok az öskeresztény hagyományokhoz nyúltak vissza, amikor a liturgia sokkal inkább közösségi cselekmény volt. A nemzeti nyelv használata és az egyházzene jelentőségének növelése pedig a liturgiát közvetlenebbé, érthetőbbé és személyesebbé tette a reformok után. Az egykori patetikus templomtér az utolsó vacsora „bensőséges otthonává” válhatott. ${ }^{41}$ „A szakrális tér következésképpen a szent fogalmához kapcsolódó, a kultuszt magában foglaló és megjelenitó térforma. Történelmi tudásunk bizonyítja a szakrális tér megkülönböztetett jelentöségét." ${ }^{42}$

A történeti templomépítészetben a külső és a belső mindig konzekvens kapcsolatban állt, azonos jelentőséggel bírtak. ${ }^{43} \mathrm{~A}$ külső a fizikai környezetbe való beágyazottság (illeszkedés, vagy épp kontraszt) szempontjából fontos, másfelől annak építészeti formálása előkészíti a belső térbe való megérkezést, ami szakrális épületek esetén még nagyobb jelentőséggel bír. A templomépítészet lényegi pontja a külsőből a belső térbe történő belépés pillanata, melyben a tér feltárulása, misztikája, majd megismerése során el lehet jutni a kontemplációig. ${ }^{44}$ Ezzel szemben az 1970-1980-as években a belső érzékelhetően hangsúlyosabbá vált. Ez részben a politikai-társadalmi helyzetből és kötöttségekből fakadó, kezdetben kényszerü, később igazolt visszafogottságból ered, másfelől a történelmi időkben oly egyértelmű torony szimbólum szerepének csökkenéséből is következik. ${ }^{45}$ Részben a szekularizáció következménye is a templom periferikus vagy nem hangsúlyos telepítése, ${ }^{46}$ magának az épületnek a hagyományos értelemben vett egyértelmüsített jelszerüsége pedig a tornyok funkcionalitásának megszünéséből adódott. A települési környezetben a korábbi 3-6 méteres épületmagasságok a városok léptékének növekedésével fokozódó építési igények miatt 30-40 méteres magasságra is megemelkedhettek. ${ }^{47}$ Ebben a kontextusban a templom megjelenése és helyzete teljesen átértékelődött. ${ }^{48} \mathrm{Az}$ új épületek között

${ }^{40}$,Vajon hol mutatkozik meg jobban az ember lelkülete, ha nem a számára oltalmat nyújtó háza megépitésében? Ugyanígy, az a mód, ahogyan templomainkat megépítjük, egyúttal megjeleníti az Egyház - azaz a Krisztus testében való közösség - életének minőségét." A liturgikus tér áttekintését és az ebből eredeztetett újraértelmezés magyarázatát adja: Bouyer 2000. Magyarországi értékelését lásd: Katona 2017.

${ }^{41}$ A II. vatikáni zsinat templomokra és templomba járókra való hatásáról: Lantos 2008.

${ }^{42}$ Török 2013. 330.

${ }^{43}$ Ennek ellenkezője igaz a keleti keresztény templomépítészetre, ahol az építtetőknek nem a külső, hanem a körülhatárolt belső tér volt a fontosabb. A belső ezeknél az épületeknél lenyügöz: a dúsan aranyozott ikonosztázion és a kupola - mint legjellegzetesebb szerkezeti elem - továbbra is központi szerepet töltött be. Templombelső és misztika kapcsolatáról a keleti egyház építészetében: Nagymihályi 1977.

${ }^{44}$ A csend szerepéröl a szakrális terekben: Katona 2016, illetve Vukoszávlyev 2011.

${ }^{45}$ A települések vertikális jellemzői a tornyok voltak: védelem, híradás és az égbe törő bizalom. A torony mint egyetemes forma végigkísérte az építészettörténetet, a szakrális építészetben pedig a föld-ég kapcsolat legközvetlenebb megjelenítője volt. A torony szimbolikus történeti jelentőségéről: Santarcangeli 1984.

${ }^{46}$ Szekularizáció és transzcendencia viszonyáról: Nyíri 1970.

${ }^{47}$ Vákár 1982. 60-63.

${ }^{48}$ Egyik, már későbbi, ám igen szélsőséges európai példája ennek a párizsi Défense negyed temploma, mely a környező felhőkarcolók között húzódik meg, s feltünőségét már éppen a kis léptéke okozza. A városépítészet léptékbeli kérdéseiről: Pogány 1976. 
a templomépítészet léptékében lemaradt - a korábban hangsúlyos torony szerepe a magasodó környezetben tehát átalakult. ${ }^{49}$

A belső térben a hierarchia a belépési ponttól az oltárhoz vezet, a templom többi része ennek alárendelt helyzetü kiegészítője. A főkapu és a szentély a figyelem kitüntetettjei, és mindez az épület külső megjelenésére is hat, ami által az egyes oldalak sem egyenértéküek, hanem azok is hierarchikusan rendezettek. A központi térrendszerủ épület alapvetően idegen volt a római keresztény templomépítészeti hagyományoktól (az Olaszországra jellemző keresztelőkápolnák kivételével). A latin rítusú templomok belső térrendje azonban ellentmondásos volt, hiszen a keresztény hit az emberek egyenlőségét hirdette, közben az egyházi szervezet szigorúan hierarchikus berendezkedésű volt. Ez a hierarchia erősen leképeződött már a hosszházas-tengelyes alaprajzi kialakításban is. A kisebb belső tér esetén könnyebb az egységes térérzet kialakítása, a nagyobb templomok irányultsága azonban megosztottabbá válik azáltal, hogy a vízszinteshez kapcsolódik egy vertikális tengely is ${ }^{50} \mathrm{~A}$ központosítást igénylő térreform tehát ezt a belső ellentétet is szándékozott feloldani.

A II. vatikáni zsinat szimbolikával foglalkozó ajánlásai a belső térformálás építészeti szempontjaihoz teológiai-liturgikus oldalról közelítettek. ${ }^{51}$ A Magyarországon - az 1960-as évek közepétől csak lassú, majd a magyar fordítás 1970-es hivatalos megjelenésével (1. ábra) már gyorsuló ütemben - bevezetett liturgikus reform amellett, hogy a templomi egyházi szertartások nyelvét általánosan minden nemzetnek a saját nemzeti nyelvének használatában határozta meg, fontos építészeti formai változásokat is hozott. ${ }^{52} \mathrm{Ez}$ utóbbinak legfontosabb eleme a hívekkel szemben történő misézés gyakorlata volt, mely az oltárasztal helyzetének megváltoztatásával a belső térszervezés újraszervezését is kívánta, vagy legalábbis ajánlotta. A zsinat liturgikus változásainak lényege a közösség szerepében rejlett, ${ }^{53}$ ami azt jelentette, hogy a

\footnotetext{
${ }^{49}$ Kathy 1977. 60-63.

${ }^{50}$ „Létrejött egy törekvés, amely e másodlagos iránynak (függőleges) szinte önálló létet kívánt adni. A négyzet fölé épitett torony az ég felé szálló gondolat irányát érvényesiti. Csakhogy ez megállitja az oltár felé nézés (vizszintes) irányultságát: éppen ott, ahol a klérus elválasztott világa kezdödik. Így megerösödik a kettéválasztás.” Tordai 1984. 98.

${ }^{51}$ VI. Pál pápa 1963-ban egy beszédében ekképp szólt a kor egyházmüvészeihez: ,,Mi nektek, müvészeknek eddig soha nem látott szabadságot adunk. Nektek, akik a modern lelki élmények hatása alatt olyan nyugtalanok lettetek, átengedjük a szabadság kísérletezését. Tegyetek, amit akartok! Nem kívánjuk, hogy bizonyos hagyomány után menjetek, sem azt, hogy bizonyos stílushoz ragaszkodjatok. Csak azt kívánjuk, hogy a müvészetetek igaz és érdemes legyen, hatékony legyen, hogy érthessük, hogy segitséget hozzon, hogy igazat szóljon és hogy általa a nép szent, vallásos fogékonyságot nyerjen. Legyetek igazán összekötve a keresztény szellemmel és kultusszal, éljetek egyetértésben vele, és akkor csináljatok azt, amit akartok...” Közli: Cserháti-Esze 1971. 105.

${ }^{52}$ 1966-1988 között a II. vatikáni zsinat dokumentumait füzetenként folyamatosan kiadta Magyarországon a Szent István Társulat (1. ábra), illetve hosszú ideig értelmező szótárak, magyarázatok jelentek meg több keresztény folyóirat hasábjain is.

Az új Római Misekönyv 1970-ben történő magyarországi kihirdetésétől kezdve alapvető követelménnyé válik, hogy a templom a kor igényeinek megfeleljen, középületként müködjön, kapcsolódjanak hozzá a legfontosabb kiszolgáló helyiségek (mosdók, átöltözés terei...). Ez a központi rendelkezés járult hozzá igazán a templomépítészet térszemléletének szimbolikus megújulásához.

${ }^{53}$ Kránitz 2002.
} 


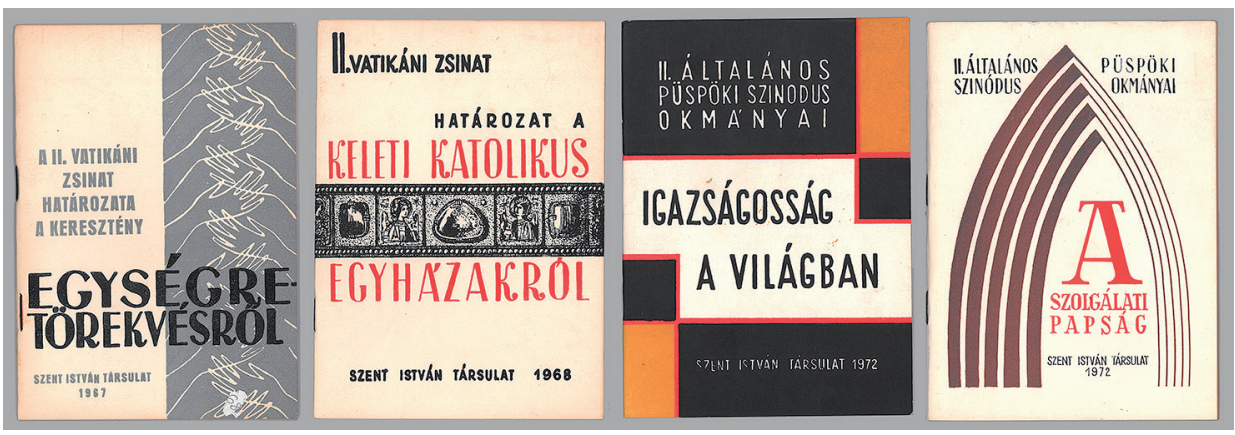

1. ábra. A II. vatikáni zsinat közleményeinek néhány magyar fordításban megjelent füzete, 1967, 1968, 1972

szentmise a korábbi imádságok sora helyett egy közös cselekedetté vált. ${ }^{54}$ Az Úr asztalának központosított (a közösség centrumában pozícionált) helyzete elengedhetetlenné vált: a központosított helyzet azonban nem feltétlenül az alaprajzi centrumot jelentette, inkább egyfajta szellemi fókuszpont megjelölését kívánta. ${ }^{55}$ További változás, hogy míg korábban nyitott gyóntatószéket használtak, a zsinatot követően megjelent a zárt gyóntatófülke, illetve füthető, kisebb gyóntatóhelyiség igénye. Az együtt misézés révén a korábbi mellékoltárok szerepe megszünt; csakúgy, mint a hívek oltárhoz való vonulásának eredményeképp a szentélyrács vagy áldoztatórács is funkcióját veszítette. A liturgikus térreform tehát az építészeti tervezésben is indokot adott a korábban nem megszokott, s immár funkció szempontjából is szükségessé váló tér- és formakísérleteknek. ${ }^{56}$

A liturgiából következő téri változások mellett a templomteret meghatározó képzőművészeti alkotások karakterére is hatással volt a II. vatikáni zsinat. ${ }^{57} \mathrm{Az}$ Isten felé

\footnotetext{
${ }^{54}$ Szigeti 1970. 76.

${ }^{55} \mathrm{~A}$ templomkép szemléletének változásáról, illetve a krisztusi közösség eszmény templomtérre gyakorolt hatásáról: Arató 1975. 394-395.

${ }^{56} \mathrm{~A}$ templomépítészetet és a meglévő templomok belső tereinek átalakítását segítendő 1971-ben megjelent Cserháti József és Esze Tamás szerkesztésében, Levárdy Ferenc és Arató Miklós közremüködésével az Egyházi épületek és mütárgyak gondozása címü könyv (Cserháti-Esze 1971), mely rövid idő alatt meghatározó alapmüvé vált. A reformok térigényeinek maradéktalan érvényesülését leginkább csak az új templomok esetében sikerült megoldani, az új építkezések mellett azonban nagyarányú túlsúlyban voltak a meglévő templomok tereinek az átalakításai. 1965 augusztusa és decembere között készültek el az első szembemiséző oltárok az országban (Budapest, Rákosfalva, Boncfölde). Turányi 1988. 44. A meglévő épületek liturgikus tereinek átalakítására szintén javaslatokat adott: Guzsik 1988.

${ }^{57}$ Fontos kiemelni, hogy az egyházművészet nem azonos a liturgikus müvészettel. A különbözőség gyakran nem egyértelmü, így számos konfliktust okozhat: „, liturgikus müvészet lényegesen nagyobb megkötöttségekkel jár. Jellemzöje, hogy a szó legszorosabb értelmében szolgálni akarja a szent szertartásokat." Alapvetö különbség, hogy míg az egyházművészeti alkotások jellemzően szubjektív megjelenésủ munkák, a liturgikus tárgyak kialakításánál az egyház egységes szándékát kell kifejezni. Éppen ezért egy magas művészi kvalitású egyházmủvészeti alkotás szubjektivitása okán nem biztos, hogy alkalmas a liturgikus müvészeti alkotássá váláshoz. Boda 1972. A liturgikus berendezési tárgyak müvészetéről: A liturgikus berendezési tárgyak és eszközök müvészete 1968.
} 
fordulást és a kontempláció elmélyítését a reformok a berendezések formai egyszerüsítésével, de magas mủvészi színvonalon, nemes anyagokból megalkotott és egységes megjelenésủ kortárs képzőmüvészeti alkotásokban és használati tárgyakban definiálták, valamint a szimbolika hierarchiájának egyértelmüvé tétele is még fontosabbá vált. ${ }^{58}$

A fény szerepe, annak építészeti megjelenítése is kitüntetettebb szerephez jutott. ${ }^{59}$ Az épített térben végzett liturgia során a szakralitás misztikáját leginkább az általunk nem befolyásolható, csupán jelenlétükkel érzékeltethető elemek adják. Az érzékelés az időbeli állandóság és a pillanatnyi változások kontrasztjából alakul: az eszményiség értéke a mulandóságban és a változásban rejlik. A liturgia a keresztény naptár előkészületi időszakai és ünnepei szerint változik: mindennek megszabott ideje van, a várakozás pedig elhozza az esemény örömteli pillanatát. Az ige és a zene liturgiája alkalmazkodik ehhez. A templomtér viszont fizikai tehetetlenségéből adódóan csak korlátozottan tud a ciklikussághoz igazodni. Az evilági mulandóság-megújulás vizuális érzékelését mutatja meg az épített térben a fény, a körülöttünk lévő világ fizikai, mégis megfoghatatlan eleme. ${ }^{60}$ A modern templomépítészet a korábban hosszú ideig hagyományosan alkalmazott fényszimbolikával szemben a változásokra koncentrál (hasonló célzatúak továbbá azon templomok is, ahol a belső tér egy kitüntetett helyen a természeti-táji környezetre van megnyitva, és annak évszakonkénti természetes változását reprezentálja). ${ }^{61}$

\section{A II. VATIKÁNI ZSINAT HATÁSA A SZAKRÁLIS ÉPÍTÉSZETRE}

Nyugat-Európában a templomépítészet formai megújulását célzó első törekvések már jóval a II. vatikáni zsinat előtt megjelentek: a historizmussal szakító templomépítészet legkorábbi példái már az I. világháború elötti évtizedre tehetőek, 1918 után pedig a modernizmus térhódításával párhuzamosan már alapjaiban új térszemlélettel jelentek meg a hagyományos formálástól eltérő templomok, elsősorban Hollandia és Németország területén. ${ }^{62} \mathrm{~A}$ II. világháború után teljesen egyértelmüvé vált a váltás igénye, Nyugat-Európában és a tengeren túli országokban sorra jelentkeztek az új

\footnotetext{
${ }^{58} \mathrm{~A}$ reform az oltártérben három fókuszpontot jelölt ki: az ambót, az oltárt és a szédeszt. Ezeket úgy kellett pozícionálni, hogy a templomtér minden pontjából jól láthatóak legyenek. A szentségőrző helyét tabernákulumban a fö- vagy mellékoltáron, illetve falba süllyesztett pasztofóriumban úgy kellett kialakítani, hogy napközben a hívek számára látogatható legyen. A liturgikus tárgyak jelentőségéről és az elemek szakrális jelentéséről a Diós-Viczián 1993-2010 megfelelő szócikke ad értelmezést. A szakrális terek jelképrendszeréről ad áttekintést: Balogh 2004. Tér-forma-szín egyházi vonatkozású kérdéseiről: Gadányi 1935.

${ }^{59}$ A szakrális térben megjelenő fény építészeti megjelenítéséröl: Meggyesi 2013.

${ }^{60} \mathrm{~A}$ fejezetben említett értelmező szempontok részben átfedésben vannak a Vukoszávlyev Zorán Tisztább képletek címủ, kortárs templomépítészeti „képleteket” áttekintő munkájában megfogalmazottakkal. Vukoszávlyev 2010.

${ }^{61}$ Az 1950-2000 közötti európai templomépítészet legkiemelkedőbb alkotásait, s ezáltal a szakrális tér megfogalmazásának változatos lehetőségeit bemutatja: Stock 2002 és Körner-Wiener 2010.

${ }^{62}$ Stock 2006.
} 
szakrális térszemlélethez kapcsolódó szerkezeti formakísérletek. ${ }^{63}$ Míg a keleti blokk országaiban az egyház az elnyomásból igyekezett kitörni, és teológiai, egyházépítészeti fejlődésre ebben a korszakban csak korlátozottan volt lehetősége ${ }^{64}$ addig a nyugodt átmenettel, de ugyancsak szekularizálódó „nyugaton” már aktív tanácskozások folytak a templomépítészet új helyzetéről, építészeti-városépítészeti kérdéseiről. Az 1961-ben Párizsban rendezett konferencián Danielou bíboros vezetésével már vizsgálták a 20. századi templomépítészet akut problémáit, illetve ugyanerről a kérdésről tanácskoztak Hamburgban is az evangélikus egyház képviselői. A katolikus és a protestáns felekezetek hasonló megállapításokra jutottak a templomok tervezési szempontjait illetően: a tekintetet az ég felé irányító torony nem feltétlen szükséges eleme a templomnak, csakúgy, ahogyan a korábbi kereszt vagy téglány alaprajzi elrendezés sem nélkülözhetetlen kívánalom. A túlságosan magas belső tér is kerülendő, mert a közösség már inkább a bensőséges és meghitt templomteret igényli. ${ }^{65}$

Az egyén és közösségeszmény II. vatikáni zsinat által újraértékelt jelentése kapcsán megváltozott a templom használói tartalma is. A római katolikus liturgia térreformjában mégsem a szentély elrendezésének téri, funkcionális átformálása a lényeg, mert a "funkcionalizmus kísértését meg kell haladnia a templomépitésnek”" ${ }^{66} \mathrm{~A}$ közösség és közösségi térhasználat ezen kritikája már az 1950-1960-as évek hazai templomépítészetében megjelenik, amikor a szakrális tér egyéb közösségi funkciók szerepére is alkalmassá válik, $\mathrm{s}$ a korábban csak szolgáló egyház lassan szolgáltató egyházzá is alakult. ${ }^{67} \mathrm{~A}$ központosítás a templomtér otthonosságának és patetikusságának szimultán jelenlétét segítette.

\section{SZERKEZET ÉS ANYAGHASZNÁLAT}

Az 1950-es években az ipari építészet a politikai akarat eszközeként kiemelt fontosságú volt, és a hazai szerkezetfejlesztés is kitüntetett jelentőségüvé vált. Az alapvetően szerkezetelvủ és anyagszerủ modern építészet - a középületeknél kötelezően

\footnotetext{
${ }^{63}$ Stock 2002. - Európai viszonylatban fontos kiemelni Rudolf Schwarz templomépítészeti munkásságát. A 20. századi hazai protestáns templomépítészetet európai kontextusba helyezi: Baku-Urbán-Vukoszávlyev 2017.

${ }^{64}$ A szocialista éra egyházak építési tevékenységére gyakorolt hatását elemzi: Stan-Turcescu 2012, Pollack 2013 és Kerekrétyová 2015, Müler-Neundorf 2012.

${ }^{65}$ Cserháti-Esze 1971. 92. - A nyugat-európai területeken a szakrális építészet II. világháború utáni szabadabb kibontakozásának és a II. vatikáni zsinat újító szellemiségének köszönhetően tömegesen épültek templomok. A század végére a templomépítészet Európa-szerte ismét az építészet és képzőmüvészet összhangjának kristályosodási pontjává vált. Stock 2002.

${ }^{66}$ Nagy 1972.

${ }^{67} \mathrm{Az}$ egyház szerepe a templomépítészet alaprajzi szervezésében is közvetlenül lekövethető: kezdetben a triumfális (dicsőséges) egyház tengelyes térszervezést követett, majd a szolgáló, közösségre koncentráló egyház a központosítást, centrumképzést részesítette előnyben. Ennek egyfajta továbbfejlődése, amikor a templomtér már mint közösségi tér is müködik a szakrális funkción kívül, s alkalmassá válik egyéb rendezvények befogadására.
} 
alkalmazott szocialista realizmus formai elvárásai miatt - ebben a korszakban leginkább csak az ipari építészetben bontakozhatott ki. Az 1960-as évek a hazai építészetben is a modern építészethez történő visszatérés időszaka. A mérnöki esztétika általános térnyerése mellett nagyobb számban fejlesztettek olyan szerkezeti rendszereket is, melyek nem kizárólag az ipari építészet elvárásaihoz igazodtak, így az építészek szabadabban alkalmazhatták ezeket az építészet más területein is - részben szükségből, részben pedig akár meggyőződésből, mert az efféle építészeti „,szerkezetiség” esetleg eleve biztosította az épület modern megjelenését. E tekintetben a templomépítészet sem volt független a kor lehetőségeitől és korlátaitól: míg az 1960-as évek templomai a modernizmus mintáit követve, de még hagyományos építőanyagokból és szerkezetekkel épültek, addig az 1970-es évektől már jellemzően a korszerübb szerkezeti rendszereket részesítették előnyben a tervezők, majd az 1980-as években az önkifejeződés szándéka által vezérelve még expresszívebb megoldások születtek. Mindemellett az 1970-1980-as évekre az egyházat érő politikai nyomás enyhülésének köszönhetően a korábban teljesen háttérbe szorított és kontrollált templomépítészetre ismét átfogóbb építőmüvészeti területként tekinthetünk.

A tervezők anyagválasztását (így a templom esztétikai megjelenését) determinálta azok hozzáférhetősége és beépítésének szaktudásigénye - mind pénzügyileg, mind jellegükből fakadóan. Az anyagok karakteréből adódóan szellemileg is körülhatárolódtak a lehetőségek; az anyagválasztás és szerkezeti esztétika kérdését tehát össze kellett egyeztetni a lelki-szakrális igényekkel is. ${ }^{68} \mathrm{~A}$ politikai körülmények korlátai miatt az épülettel szemben támasztott elvárások használói oldalról pillanatnyilag leszükültek, hiszen az építés lehetősége már önmagában is eredménynek számított.

Mủemléki templomok helyreállításában szerepet vállalt az állam, azonban az új építések költsége az egyházat, de leginkább az építtető közösséget terhelte. Részben ez az oka annak, hogy a legnagyobb repressziót jelentő 1960-as években, de még a vizsgált korszakunk első éveiben is, a már általánosnak mondható technikai fejlettség ellenére legtöbbször a hagyományos anyagokat és szerkezeteket alkalmazták, a kivitelezést pedig nem szakemberek végezték. Ahol nem volt lehetőség korszerủ anyagok beépítésére, ott az építészek követték a tradicionális tervezési elveket és építési módokat, az általuk adta korlátok között igyekeztek egyedi építészeti részleteket alkalmazni.

Az anyagi lehetőségek mellett a tömegesen alkalmazott építő és felületképző anyagok használatát erősen meghatározták a kor politikai-társadalmi igényei is. A II. világháború utáni szocialista realizmus ideológiai elvárásai az állami reprezentációt helyezték előtérbe, így a legnemesebb felületképzések kialakítása elsősorban a nagy közönségforgalmú épülettípusokra korlátozódott. A templomépítés tiltott tevékenység volt, így az építészeknek a templomépítészet tradicionális, nemes anyagai helyett (a modern újító és kísérletezési szándékával nem azonos módon) szükségszerüen új formai megoldásokat vagy az alapvetően lokális anyagok adta alkalmazási

\footnotetext{
${ }^{68}$ Puskás-Perendy 2013.
} 
lehetőségeket kellett keresniük, melyben a szakralitás kifejezhetőségét látni vélték. ${ }^{69}$ Az 1970-1980-as évek templomépítészetében anyag- és szerkezetválasztás terén nehéz tendenciákat megállapítani, és talán nem is lehet közös nevezőt találni, mégis, ahol a tervező igazán mủvészi felfogással közelített feladatához, ott mindenhol megjelent a merészségg. ${ }^{70}$ Kísérletezés és találékonyság érhetö tetten a szakrális építészetben még korábban ki nem tapasztalt szerkezeti elemek és felületképző anyagok alkalmazásában, azok szokatlan kombinációiban, valamint a teherhordó szerkezetek statikai határainak keresésében.

Az állami tervezőirodákban dolgozó és alkotó építésztervezők kollektívája a nemzetközi trendekre való szélesebb körủ rálátásának és az Európa-szerte terjedő új építőanyagok első kézből történő megismerésének köszönhetően hatással volt az újonnan épülő templomok szerkezeti-építészeti kialakítására. ${ }^{71} \mathrm{~A}$ felületképző anyagok köre kiszélesedett azáltal, hogy a korábban takart helyzetben beépített elemek láthatóvá váltak: a raszteresen sorolt, látszó szerkezetek a templomépítészet terén a korábban megszokottól eltérő, újfajta esztétikai hatást, gyakran nyers megjelenést eredményeztek. A célszerüség, az egyszerüség és az anyagszerüség tervezési alapelvekké váltak. A gazdaságosság kreatív gondolkodást kívánt, és motiválta az építőmüvészeket az anyagok természetes tulajdonságainak őszinte megjelenítésére, így a burkolatok és díszítmények alkalmazása a korábbihoz képest gyakorlatilag visszaszorult $^{72}$ (2. ábra).

Ugyanakkor a korszerủ építési gyakorlatban alkalmazott megoldások néha analógia jellegü átvétele esetenként ellentmondásokat okozott: a templomok speciális használatához nem mindig kellő körültekintéssel igazították a már ismert világítási és szellőzési megoldásokat, így a használók komfortérzete esetenként komoly hiá-
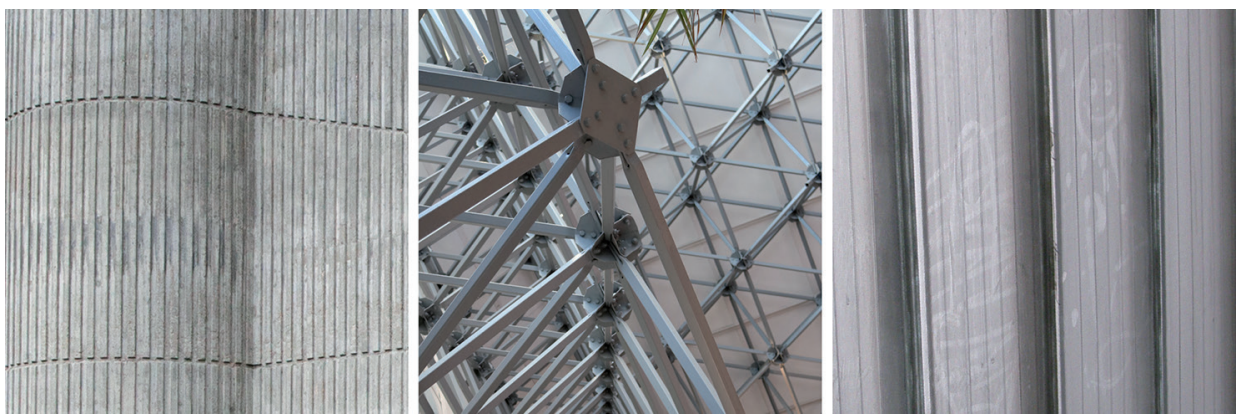

2. ábra. Iparias felületek és textúrák: monolit vasbeton (Nemeshetés, Szent László római katolikus templom), KIPSZER acélszerkezet és profilüveg pallók (Budapest, Szent Kereszt római katolikus templom) (Fotók: Urbán Erzsébet, 2017)

\footnotetext{
${ }^{69}$ Egy barokk templom nemes és kimunkált márványfelülete feltűnően és egyértelmüen hirdeti az építési szándékot, míg egy hétköznapi elemekböl, az egyszerüség jegyében rakott nyers felület a mindennapi eröfeszítések szépségét közvetíti.

${ }^{70}$ Rév 1984. 84.

${ }^{71}$ Szendröi 1972.

${ }^{72}$ Szendröi 1965. 10.
} 
nyokat szenvedett. Ez a probléma leginkább a tető-felülvilágítók alkalmazásánál került elő, ahol az árnyékolás hiányából és a levegő természetes keringésének megoldatlanságából fakadóan a nyári túlmelegedés általánosan előfordult. ${ }^{73}$ Gyakorivá vált a drótüveg és a profilüveg (profilglas vagy üvegpalló) alkalmazása is, melyeknél a fix szerkezetből adódóan is közel 30\%-kal olcsóbb bekerülési költséggel lehetett számolni, mint a mozgatható szerkezetekkel kialakított nyílászárókkal készülő üveghomlokzatok esetén. A megtakarításból a függetlenített szellőzés biztosítható lett volna ugyan, azonban ez legtöbbször elmaradt. ${ }^{74}$

Az ipari szempontból viszonylag gyengén fejlett magyarországi nehézipar hiányosságai miatt az acélszerkezetek alkalmazását jellemzően kerülték templomok esetében, ugyanakkor a vasbeton létrehozásához szükséges adalék- és cementszükséglet könnyebb biztosíthatósága miatt ekkoriban a vasbeton szerkezetek intenzívebben fejlödtek hazánkban. A monolit szerkezetek helyszíni betonozása ugyan munkaigényes volt, ám a zsaluzat összeállítása és a helyszíni öntés még mindig gazdaságosabb volt, mint az acélszerkezetek üzemi elóállítása és helyszíni összeszerelése. ${ }^{75}$ A monolitikus építésmód kiválóan alkalmas volt a nem tipizálható, egyedi megoldású építmények kialakításához, így a korszakban Magyarországon is gyakoribbá váltak a vasbeton falakból és födémekből kialakított templomok. ${ }^{76}$ A helyszíni elöregyártás és az üzemben előregyártott elemek alkalmazása a léptékből és a szállítási, állványozási költségekből fakadóan nem volt jellemző.

Acélszerkezetek inkább már a korszak második felében fordultak elö, és az acélpillérek mellett a nagy fesztávú áthidalások is készülhettek acélszerkezetủ tartókból, térrácsokból. ${ }^{77}$ Ezen elemek alkalmazása a korábbi hazai templomépítészetben alapvetően idegen volt, így a szokatlan látvány nem minden esetben nyerte el a hívek tetszését és esztétikai elvárásaiknak kifejezetten ellenére volt. Az acélszerkezetek alkalmazásánál azonban a kivitelezés során a technológiai szakszerüség és a csatlakozások helyes kialakítása különösen fontos volt ahhoz, hogy a későbbi épületfizikai problémák elkerülhetőek legyenek. A II. világháború után gyorsabban terjedő vékonyfalú vagy könnyủ acélszerkezetek (illetve egyéb új anyagok, mint például az alumíniumkonstrukciók vagy a különböző könnyübetonok) alkalmazása nem fordult elő a hazai templomépítészet gyakorlatában. ${ }^{78}$

A leggazdaságosabb megoldás mindig az adott helyi, anyagi lehetőségektől függött: új anyagokat akkor ajánlhatott a tervezö, ha ezt a körülmények lehetővé tették. A méretegyeztetés, ritkábban modulban tervezés és a szerkezetek szakértelmet igény-

${ }^{73}$ Ali 1970.

${ }^{74}$ Szendrői 1965. 53.

${ }^{75} \mathrm{Az}$ élőmunka kedvezőbb biztosíthatósága mellett azonban a zsaluzat faanyaga hiánycikknek számított: az ország famérlege alapján a felhasználás nagy része külföldi behozatalból származott. Szendrői 1965. 82.

${ }^{76} \mathrm{Ez}$ a tendencia Nyugat-Európában már a két világháború közötti időszakban elkezdett erősödni, a tengerentúlon pedig a II. világháborút követő években kezdett intenzíven terjedni a monolit vasbeton szerkezetü templomok tervezése. Stock 2006, illetve Friedman 2010.

${ }^{77}$ Acélszerkezetek alkalmazásáról és előnyeiről: Seregi 1995, Seregi 2001 és Seregi 2002. A korszerü nagyfesztávú térlefedő szerkezetekről áttekintést ad: Horváth-Csernoch 1970.

${ }^{78}$ Friedman 2010. 
lő helyszíni szerelése mellett a technikai és az esztétikai megoldások közötti egyensúly megteremtése is fontos szempont volt. Magyarországon az egyre növekvő, összefüggő üvegfelületekkel, és a vázrendszert szabadon hagyó belső térformálással csak az 1970-es évek közepétől kezdtek kísérletezni a tervezők. Ennek köszönhetően, ugyan nem nagy számban, de a hazai templomépítészet területén is megjelentek azok a 20. században elterjedt szerkezetek és építőanyagok, melyek nemzetközi szinten már a II. világháború előtt is előfordultak a templomterekben.

\section{ALKOTÓI MÓDSZEREK}

A fejlődő, váltakozó építészeti tendenciák sorában azok az épületek tudtak hosszú távon minta értékủvé válni, melyek a tradicionalizmus és a modernizmus (korszerüség) közötti harmonikus egyensúlyt leginkább közelítették. ${ }^{79}$ E fejezet az $1970-1980$ as évek templomépítészetében leginkább kiemelkedő tervezők egyes templomainak rövid bemutatásával kívánja érzékelhetővé tenni a szocializmus korszakának szakrális építészeti kihívásait, és az ezekre adott lehetséges alkotói válaszokat. A sajátossá finomodó tervezési metódusok kialakulásában fontos szerepe volt a meglévő történeti példák és a fejlődő világ adta újszerü technikai lehetőségek párhuzamos alkalmazásának. A tervezőknek elengedhetetlen volt, hogy megismerjék az anyagok és szerkezetek nyújtotta építészeti lehetőségeket külföldi példák és a szaksajtó által, ugyanakkor az is nélkülözhetetlen volt, hogy az akkori magyar építési gyakorlat technológiai-anyagi korlátait belássák, s mindent a hazai lehetőségekhez mérten kívánjanak alkalmazni. A bemutatás a szerkezethasználatból eredeztethetó értékek kiemelését célozza, hiszen ezek jól szemléltetik a korszak egyházi építési tevékenységének problémakörét is. Minden esetben hangsúlyos volt a közösség szerepe, mely nemcsak az építési szándékban, hanem a kivitelezésnél, megvalósításnál is megmutatkozott.

A II. világháború utáni hazai templomépítészet ezen két évtizedére az egymás mellett párhuzamosan megjelenő és egymástól gyakran igen eltérő tervezői szemléletek együttes jelenléte jellemző. Mégis a különbözőnek tünő karakterek ellenére az irányok gyakran több ponton összeérnek és átfednek. A kutatás az épületeknél alkalmazott szerkezetek, az ebből részben már egyértelmüen következő forma ${ }^{80}$ alapján létrejövő esztétikai élmény és funkcionális térhasználat ${ }^{81}$ szerint elemzi az emlékeket. A tanulmány a hangsúlyt a római katolikus templomépítészetben történt változásokra helyezi, mivel az összes templomépítkezéshez képest ezen felekezet arányaiban nagyobb számú templomot építtetett, illetve a korábban megszokott tervezési elvekhez képest itt történtek a legjelentősebb változások. Az áttekintés a hagyománykövető hosszanti elrendezés és a korszakban egyre gyorsabban terjedő centrumképző

\footnotetext{
${ }^{79}$ Moravánszky 1984.

${ }^{80}$ Kizárólag szerkezet és forma viszonyát vizsgálja: Gilyén 1982.

${ }^{81}$ Funkció és forma viszonyát elemzi a kortárs szakrális építészetben: Körner-Wiener 2010, illetve nemzetközi viszonylatban: Pallister 2015.
} 
térkoncepciók megjelenését vizsgálja az épületeknél alkalmazott szerkezeti rendszerekkel való összefüggésben. A II. vatikáni zsinat liturgikus reformjára választ adó kísérletező tervezésmód főként a szentély különleges, legtöbbször rejtetten történő megvilágítását kísérelte meg, de persze ettől jelentősen eltérő, a hagyományokkal szakító újfajta megnyitással is találkozhatunk. A szellemi vagy építési minőség alapján válogatott emlékek szerkezeti jellemzői szerint történő rendezésével olyan lehetséges építész alkotói utak összefüggései vizsgálhatóak, melyeknek az épületek saját élettartamán túlmutató hatásuk volt. Tendenciakijelölés helyett pedig a kutatás inkább a maradandó értéket teremtő építészeti gondolkodási modellek felszínre hozását célozza. ${ }^{82}$

\section{CSABA LÁSZLÓ}

A templomépítések korlátolt megvalósítási lehetőségei miatt a tervezésnél az egyszerüségre törekvés alapkövetelmény volt, hiszen , lényegében házilagos kivitel állt rendelkezésre, néhány ügyes, szakmáját tudó és szeretö mesterember bevonásával, akik sokkal inkább a terv gondolatait akarták megérteni és megvalósitani, semmint a tervet megmásítani" ${ }^{83}$ Ez a tervezői szemlélet érhető tetten a kívülről zárt megjelenésủ hodászi Szent Pál megtérése római katolikus templom (tervező: Csaba László; építés évei: 1973-1976) esetében is, ahol felekezetre való tekintet nélkül az egész falu részt vett az építésben, valamint a termelöszövetkezet gépekkel, fuvarral és építőanyagokkal segítette a kivitelezést. ${ }^{84} \mathrm{~A}$ vasbeton vázzal és falazott kisméretű téglakitöltéssel épült templom kívül-belül fehér vakolt felületképzést kapott. A törtvonalú terpesztett elrendezést merevíti az oldalirányban fellépő erőkkel szemben az összekötő acélgerendázat. Míg a tető, s így a belső tér is az oltár felé emelkedik, addig a templomhajó alaprajzilag szúkül a szentélyhez közeledve. A természetes palafedésű tetősíkok eltérő magasságban történő záródása miatt az itt elhelyezett színes üvegablakon át dinamikus megvilágítást kap a szentély, melynek hátsó, ferde falsíkját borító, mennyezetig tartó szekkóját Kákonyi Asztrik készítette. A festmény színeinek tónusa felfelé halványodik, eközben a színes fény éppen errefelé erősödik. Mind a tér, a kép és a fény is a tekintetet nagyon erösen felfelé orientálja. ${ }^{85}$

Sajátos formakísérletek a korszakban a spirális alaprajzi rendszerre szerkesztett templomok. Nagyvárosi lakótelepek közelében épült a kaposvári Szent József római katolikus templom (tervező: Csaba László; építés évei: 1983-1988). A tervező építészetére jellemző síkokkal határolás egyedül ennél az alkotásánál nem érvényesül: az

\footnotetext{
${ }^{82}$ A korszak építészeti tendenciáiról az 1981-ben az Óbudai Galériában Szegő György és Gerle János által rendezett Épitészeti tendenciák Magyarországon 1968-1981 kiállítás kapcsán: Beke 1984 és Csete és mtsai 1984. Az építészeti tendenciák létjogosultságának kérdéséről: Ferkai 1984, illetve stíluskérdésekről: Janáky 1984.

${ }^{83}$ Csaba 1978. 41-42. - Fontos előzménynek tekintendőek Csaba László Cserépváralján vagy Hollóházán épült templomai.

${ }^{84}$ Rév 1987. 66-70.

${ }^{85}$ Lukács 1989. 56. Vukoszávlyev 2017. 107-110.
} 

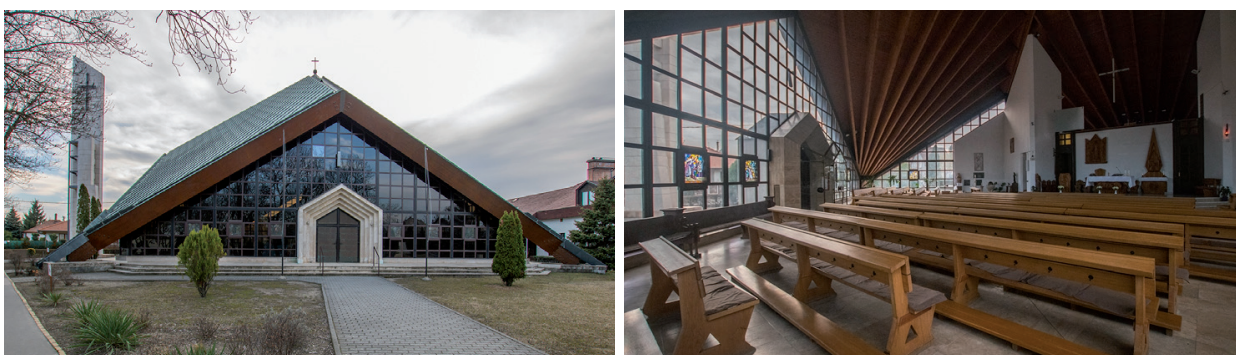

3-4. ábra. Budapest, Boldog Özséb római katolikus templom, 1985-1987 (templom melletti harangtorony: 2003). Építész: Csaba László (Fotó: Urbán Erzsébet, 2019)

életvonalat jelképező, csigaházszerü tömeget létrehozó falak nem csak vetületükben, de magasságukban is változnak. A tér az oltárig emelkedik, ahol a szentély a templomtér leghangsúlyosabb pontjává válik. A spirál legbelső és egyben legmagasabb pontja alakítja ki, illetve pótolja a nem építhetö tornyot. ${ }^{86}$

Vasbeton szerkezetek megvalósítására nem mindig volt lehetőség. Az egyszerú és áttekinthető rendszerrel, tiszta anyaghasználattal épült budapesti Boldog Özséb római katolikus templom (tervező: Csaba László; építés évei: 1985-1987) sátor, illetve ernyőszerü lefedését eredetileg vasbeton lemezből szerette volna a tervezö, azonban ennek költségét és kivitelezését nem tudta a közösség finanszírozni, így végül a valamivel olcsóbb, Agárdon gyártott, rétegelt ragasztott fatartós rendszer mellett döntöttek ${ }^{87}$ (3-4. ábra).

A II. világháborút követően a technikai lehetőségek bővülésével az építészet kifejezőeszközei is kibővültek. A lehetőségek ugyan gazdagabbá váltak, mint korábban, azonban az építészeti színvonal eléréséhez az új technológiákhoz megkívánt gépek és kivitelezési módszer is elengedhetetlen volt. A közösségek korlátozott pénzügyi helyzete, az építőanyagok beszerezhetősége és a „házilagos” kivitelezési tech-

\footnotetext{
${ }^{86}$ Ugyan nem íves, hanem törtvonalú elrendezést mutat, de hasonló koncepció szerint formálódott a pécs-postavölgyi Szent László római katolikus templom (tervezö: Gettó József; építés éve: 1981). A csigaszerủen magába forduló, szoborszerủ templom mesterien alkalmazza a korszak hazai építési színvonalának lehetőségeit, éppen annyit és olyan mértékben, amivel még a színvonalas kivitelezés biztosítható. A fehér, plasztikus épülettömeg minden irányból más megjelenést mutat. A csavarodó vasbetonfalak és a két emelkedő törtvonalra fektetett acél rácsostartó rendszer iparias jellege ellenére bensőséges érzetet kelt, ahol az oltárteret a középpont felé emelkedő tömeg hangsúlyozza. Az épületről részletesebben: Rév 1987. 79-84.

A spriláis motívum nem feltétlen mindig a tervezett templom tömegében volt tetten érhető: Halásztelken a kétszintesre tervezett Árpád-házi Szent Erzsébet római katolikus templom (tervező: Csete György; építés évei: 1976-1980) bejáratához egy spirálisan felvezető rámpán lehet feljutni, melyhez a környező terepet is rendezni kellett. Alsó szintjére került a plébánia, a szabályos félgömb formájú felső rész pedig maga a templomtér. A kompakt tömegủ épület teljesen szabályos belső tere a kupola középpontjából kapja a megvilágítást. A belső és külső karaktert is egyaránt meghatározó íves fatartók cikkelyesen osztják a gömbhéjat, és a szabályos ritmusnak köszönhetően erősítik a felület fény-árnyék játékát. A tartószerkezeti rendszert Dulánszky Jenő statikus tervezte. Bővebben az épületről: Rév 1987. 87-92, illetve Wesselényi-Garay 2010. 168-171. Dulánszky Jenő és Csete György közös pályafutását bemutatja: Csete 2001.
}

${ }^{87}$ Lukács 1989. 
nika nagyban determinálta a döntési lehetőségeket. ${ }^{88}$ Ezen tényezők teljes körü figyelembevételéhez nélkülözhetetlen volt a mérnöki-alkotói találékonyság, fantázia és racionális gondolkodás.

\section{TÖRÖK FERENC}

A történelmi egyházak a képzőmüvészetek és az építészet mecénásaiként a hagyományos értékek őrzését mindig feladatuknak tekintették. A tradicionalizmus ${ }^{89}$ itt nem a forma, hanem a gondolkodás állandósága és természetes fejlődése, a meglévő építészeti struktúra vizsgálata, értelmezése. Ez a gyakorlatban legtöbbször azt jelentette, hogy a hossztengelyes szerkesztés a zsinatot követő formakísérletek ellenére továbbra is általános és népszerüen alkalmazott elrendezés volt. ${ }^{90}$ Ennek ellenére szerkezet és forma viszonylatában az egyéb átlós és sugaras elrendezések is anyaghasználatukban lehettek hagyománykövetők. ${ }^{91}$ Az épületek ezen csoportjába sorolhatjuk a templomépítészetben is megszokott, hagyományos építőanyagokból készült épületeket, ahol a tégla, kő és esetenként faanyagú falazat és faanyagú tetőszerkezet mellett legfeljebb a megnyitások - üvegfelületek - elhelyezése és nagysága tért el a két világháború közötti komponálástól. Lényeges különbség azonban a környezetben történő léptékváltás - mely ráadásul az egyház társadalomban elfoglalt helyzetével is összefüggött. Ennek megfelelően a vizsgált épületek elsősorban falusi, illetve kisvárosi környezetben találhatóak.

A korszakban nem volt könnyü megfelelő telket találni a tervezett templomoknak. Török Ferenc templomépítészeti munkásságában szép példáit találhatjuk meg a genius loci érvényre jutásának. ${ }^{92}$ A révfülöpi Munkás Szent József római katolikus templom esetében (tervező: Török Ferenc; építés évei: 1978-1981) a falu szélén, az ideiglenesen szükségimaházként használt, egykori nyaraló L alaprajzára kellett az új épületet ráilleszteni. ${ }^{93} \mathrm{Az}$ építőanyagok a helyi hagyományokat követve a balatonalmádiból származó vörös homokkő, fürészelt faáru és a tetőfedésnél természetes pala ${ }^{94}$ (5-6. ábra). A tradicionális anyaghasználat ellenére a homlokzati megnyitások korántsem szokványosak: nagy, egybefüggő üvegfelületek tagolják a kő- és faburkolatos sávokat. A tömeg meghatározó eleme a nyaralók kéményeire emlékeztető, a ház méreté-

${ }^{88}$ „A külső körülmények - az egyház és az állam éppen aznapi viszonya, a világ folytonos változása döntő módon befolyásolták és meghatározták templomaim választott szerkezetét...” Csaba 1990. 193, illetve visszatekintés az építész szakrális életmüvére: Csaba 2014.

${ }^{89} \mathrm{~A}$ kortárs szakrális építészetben megjelenő tradicionális formálásról: Katona-Vukoszávlyev 2012.

${ }^{90} \mathrm{~A}$ szakrális terek tengelyes szervezésének kortárs továbbéléséről: Katona 2014.

${ }^{91} \mathrm{Az}$ 1970-1980-as évek templomépítészetét liturgikus térformálás szempontjából vizsgálja: GaraiVukoszávlyev 2017.

${ }^{92}$ Török Ferenc építésszel az 1970-es évek hazai templomépítészetéröl történt beszélgetést, interjút közli: Vukoszávlyev-Garai 2017. Török Ferenc korai templomainak értékeléséröl: Garai-Zsembery 2017.

${ }^{93}$ Rév 1987. 85-86, illetve Garai-Zsembery 2017. 16-17.

94 „Természetes anyagokkal, helyi mesterekkel, a pannonhalmi bencés gimnázium növendékeinek nagyfokú társadalmi munkájával épitettük fel a »házat«.” Török 1985c. 35. Múlt és jelen építészetben betöltött szerepéröl: Török 1985a. 



5-6. ábra. Révfülöp, Munkás Szent József római katolikus templom, külső és belső, 1978-1981. Építész: Török Ferenc (Fotó: Urbán Erzsébet, 2017)

hez képest igen nagy, harangtoronyként szolgáló kőpillér. A templomtér a kis lépték ellenére tágas hatású, a bejárati üvegfelület vizuálisan összekapcsolja a külső térrel. A falak kívül-belül vakolatlanok, a nyers kőfelület látszik. A templom elötti, három lépcsőfokkal kiemelt teresedés magyarázatot ad az oltár elhelyezésére, hiszen a kitárható nagy ajtóknak köszönhetően az épület alkalmas egy nagyobb létszámú - kint és bent is helyet foglaló - gyülekezet számára is. Ebben az esetben azonban az a szokatlan szituáció áll elö, hogy a pap a hívek egyik felével szembe fordulva, a másik felének háttal állva tartja a misét. Ez a megoldás a nyári vasárnapok ugrásszerü látogató növekedéséhez való alkalmazkodást, állandó létszámingadozást kívánta kompenzálni. ${ }^{95}$

A templomtervezési feladatokban történő léptékváltás és településszövetben való elhelyezés megváltozása talán leginkább az Ábrahámhegyen álló Szent László római katolikus templom (tervező: Török Ferenc; építés évei: 1986-1988) tervezési-építési folyamatán követhető nyomon. A tervezés előkészítő szakaszában a tájegység hagyományához illeszkedve, a község központi magaslatára, a Bökk-hegyre szerették volna a templomot építeni. Már készen voltak a tervek, amikor az egyházi elöljáróság a helyszínválasztástól teljesen elhatárolódott. A település plébánosa félvén, hogy leáll az egész kezdeményezés és támogatás, gyorsan vásárolt egy kis telket a település belterületén. Az új tervezési helyszín egy mély fekvésủ, keskeny telek volt, belesüppedve a környező lakóházak övezetébe. A telekválasztás már önmagában is jól szemlélteti az egyház helyzetének és szerepének megváltozását. A korábban magát büszkén vállaló és hirdető egyház egy sokkal bensőségesebb közösséggé alakult, így a

\footnotetext{
${ }^{95}$ A II. vatikáni zsinat kiemelte a vasárnap reggeli istentisztelet fontosságát, részben ezért is létesültek ezt követően nagyobb számban a Balaton környékén templomok. Bővebben: Garai 2015.
} 
templomépítés sem hatalmi-társadalmi státuszt kellett, hogy mutasson a hegyoldalon. Az épület körül idővel épültek sorra az egyre nagyobb méretü lakóházak, így mára végül szinte teljesen beleolvad a környezetébe. ${ }^{96} \mathrm{~A}$ hossztengelyre szervezett belső tér meghatározó látványeleme a nyitott fa fedélszék. A nyeregtető gerince éppen a padsorok mellett alig félszint magasan kiemelt karzat mellvédjének vonalára lett szerkesztve, ez a templomtér legmagasabb része. Az alig egy sor ülőhelyet és közlekedősávot elfoglaló karzat másik érdekessége az épület szentély mögötti részére helyezett gyülekezeti szoba, mely kis erkéllyel nyit a templomkertre.

Török Ferenc alkotói munkásságában az építőmesterek építészeti- és életszemléletének átörökítése mellett meghatározó volt az utazások és személyes bejárások révén a környező világ müvészi megismerése is (a dolgok kéz és rajz által történő letapogatásával). ${ }^{97}$ Alkotásaiban a szerkezetiség inkább az anyagok, felületek és textúrák hangsúlyát erősíti. A nemeshetési Szentlélek római katolikus templom (tervező: Török Ferenc; építés évei: 1973-1976) építésénél hangsúlyos tényező volt a közösségi összefogás, az építési munka közösségépítő ereje. A faluban több, szakmájához jól értő ácsmester élt (akik a Zala megyei építőipari vállalatnál zsaluzással foglalkoztak), így a plébános külön kérése volt, hogy betonszerkezet és betonhomlokzat legyen tervezve. Ehhez alkalmazkodva az építész eredeti elképzelése egy roncsolt, homogén felület volt, ám a bordás zsaluzás olyan szépen sikerült, hogy a mesterek nem voltak hajlandóak összetördelni a finom éleket, így a közösség akarata érvényesült, és a ház kívülről rajzosabb-vonalasabb megjelenésủ maradt. ${ }^{98} \mathrm{~A}$ belső erős kontrasztban áll a külső kemény megjelenésével, itt a sima, vakolt felületek dominálnak. A legyezőszerü elrendezés, a diagonális feltárás a tér központosítása irányába tett korszerü kísérlet. A tervező későbbi templomainak azonban már tudatos szerkesztési elve volt, hogy ,irányt vigyen a centrális térbe”. ${ }^{99}$

A balatonfenyvesi Arpád-házi Szent Erzsébet római katolikus templom (tervezö: Török Ferenc; építés évei: 1975-1977) szintén nagy létszámingadozású üdülőterületre épült, ahol változó számú és összetételü közösséggel kellett számolni. Az 1970-es évek elején ismét felerősödött a korábbi építési szándék, s a meglévő alaptestek felhasználásával, de új templom tervezésével bízták meg az építészt. A közeli Balatonkeresztúri Fém Szövetkezet építőanyag és acélszerkezet-szerelés tekintetében nagy segítséget jelentett, így már a tervezésnél egyfajta ,,szakrális jellegü csar-

\footnotetext{
${ }^{96}$ Török 1986. 20.

${ }^{97}$ Török Ferenc az 1977-es edelényi görögkatolikus templom tervezési megbízása révén háromhetes görögországi tanulmányútra indult. A Meteórákban töltött idő, Rhodosz és Athosz környéke meghatározó benyomást tett rá a későbbi alkotói tevékenység szempontjából. Olaszországban, illetve Erdélyben is a település, az életstílus és az épületek szerves egységét, szoros összhangját figyelte meg. Török 1996. 22-24.

${ }^{98}$ Ezen az épületen erősebben érződnek a külföldi példák hatásai. A koncepció kialakítására nagy hatással volt Carlo Scarpa építészete. Scarpa mellet Török Ferenc építészeti karakterének fejlödését befolyásolta többek között lelki vonatkozásban Hegedüs Viktor (Honor atya), építészek közül kiemelten: Medgyaszay István, Weichinger Károly, Aurelio Galfetti, Luis Kahn. Török-Török 2016. 4-5.

${ }^{99}$ Török Ferenc épületeinél a szakrális tér önálló, önmagában jelen levő funkció, ,, a rejtözködö hit csodálatos megnyilvánulása”. Török-Török 2016. 46.
} 

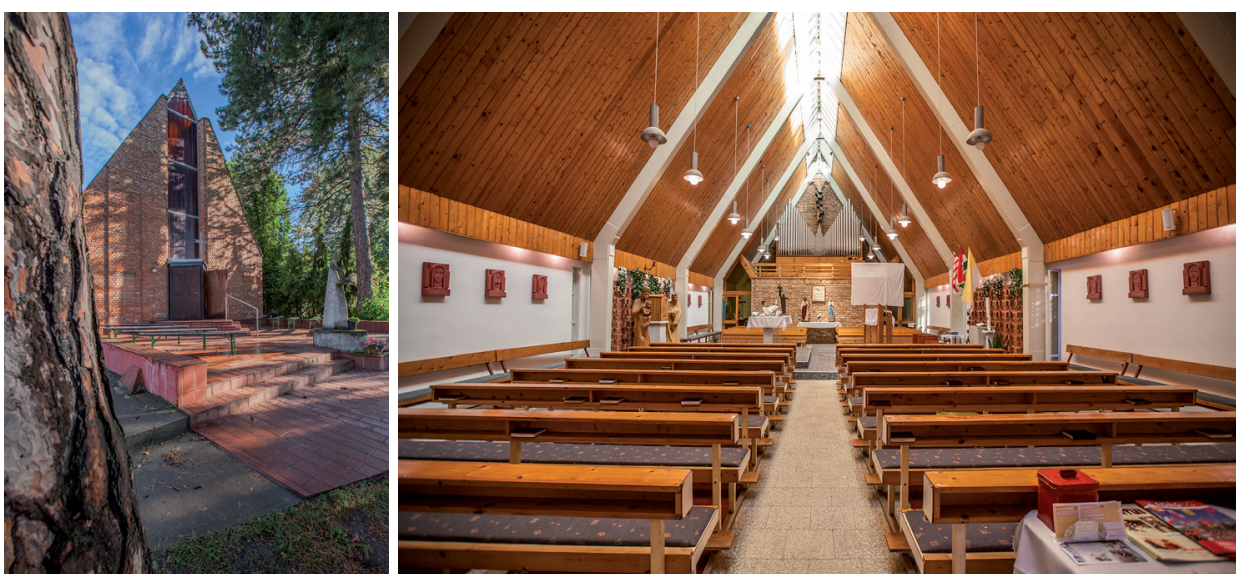

7-8. ábra. Balatonfenyves, Árpád-házi Szent Erzsébet római katolikus templom, 1975-1977. Építész: Török Ferenc (Fotó: Urbán Erzsébet, 2017)

noktér" ${ }^{100}$ kialakítását tủzte ki célul a tervező101 (7-8. ábra). Háromcsuklós acél vázkeretek és méretmodulban tervezett téglafalak készültek, az épület egy kompakt tömegbe vont egység. ${ }^{102}$ A tetőgerinc mentén végigfutó megnyitás egyfajta „,szakrális kitekintő”, mely az ipari épületek sáv felülvilágítóit idézi. Az egyetlen „díszítőelem” a napjárással dinamikusan változó fény. A hosszanti térben középen helyezkedik el a szentségőrző-oltárasztal-ambó-keresztelökút együtt komponált térszigete. ${ }^{103}$

A kis lépték alapvetően nem igényelte a különleges tartószerkezeti elemek alkalmazását, így a hagyományos anyag és szerkezethasználat a tervezői fantáziát is a megszokott tömeg- és térformálás felé mozdította. A II. vatikáni zsinat reformja szerint elhelyezett szembemiséző oltár eltérő pozicionálásán kívül nem igazán voltak újszerü belső rendezési elvek, egyedül az oltártér megvilágítása és a tetősíkok által keltett mélységérzet az, ami erős hatást eredményezett e templomokban. ${ }^{104}$

${ }^{100}$ Török 1985b. 36-37. A templomról még: Garai-Zsembery 2017. 14-15.

${ }^{101}$ A főhomlokzat formálásában szoros párhuzam érezhető Kálmán Ernő debreceni Szent László római katolikus templomának megjelenésével. Ott is a szinte földig nyúló jellegzetes nyeregtetőformát középtengelyében határozottan kettévágja a bejárati kapu sávja.

${ }^{102}$ A keretváz szerkezet adta térformálási lehetőségek tekintetében rokonítható a kunadacsi Szent István római katolikus templommal (tervező: Kerényi József; építés éve: 1974), mégis abban az esetben egészen más elrendezésü a belső tér.

${ }^{103}$ „A fenyvesi templom - úgy érzem - már teljesen tiszta formavilágú. És körülbelül ekkortól vált bizonyos mértékig stílustörekvésemmé, hogy az épületeimnek tiszta mérnöki, tiszta szerkezeti gesztusa legyen...” Török 1996. 40.

${ }^{104}$ Bár az oltártérre történő koncentrációt alapvetően a ferde síkok eredményezik, azonban míg Csaba László templomainál jellemzően alacsony ponton, „föhajtás” kíséretében léphetünk a templomba, addig például a nagydobszai Szent István római katolikus templom (tervező: Török Ferenc; építés évei: 1972-1975) esetében a tér éppen összeszükülése révén fókuszál az oltártérre. (A templomról: Garai-Zsembery 2017. 11-12.) A hasonló tömegformálás ellenére azonban éppen a szentély felé emelkedő kialakítású az alsóörsi Boldog Gizella királyné római katolikus templom (tervező: Vincze Csaba; építés évei: 1985-1987), ahol a bejárati 


\section{SZABÓ ISTVÁN}

A szocializmus által támogatott előregyártott, vagy félig előregyártott és helyszínen szerelt épületszerkezetek ipari jellegükkel profán módon hatottak a templomterekben, mégis esetenként logikus megoldásnak tủnhetett betervezésük, hiszen beszerzésük egyszerübb és megbízhatóbb volt. Az egykori anyagválasztások ma is jellegzetes elemei az épület esztétikai megjelenésének ${ }^{105}$ és gyakran a liturgikus tér használhatóságára is hatással vannak. ${ }^{106} \mathrm{~A}$ közösségek legtöbbször ellentmondásosan fogadták a megítélésükben merőben új megoldásokat, és a hagyományostól eltérő megjelenésük miatt csak ideiglenes épületként tekintettek új templomukra. Ami ideiglenesnek tünt, az mégis állandósult, és ezen épületek azóta is változatlanul betöltik funkciójukat. Mára javarészt modernizálásra szorulnak az anyagok avulása miatt, de gyakran a nem megfelelően kialakított szerkezeti részletek, valamint az időközben növekvő komfortigények okán felmerül átalakításuk szükségessége.

A templomépítészetben korábban nem használt, új anyagok szükségszerüen újfajta, kreatív tervezési és munkamódszerek alkalmazását kívánják meg a tervezőktől. ${ }^{107}$ A budapesti farkasréti Mindenszentek római katolikus templom (tervezö: Szabó István; építés évei: 1975-1977) a „betongótika” magyarországi példájaként is emlegetett épület. ${ }^{108}$ A Farkasréti temető bejáratánál lévő kápolna a II. világháború alatti harcok során súlyosan megsérült, és a teljes elbontása vált szükségessé. Az új templom építésére oly módon lehetett engedélyt szerezni, ha a már meglévő istentiszteleti célra használt szükségkápolnaként müködő étterem helyén építik fel az új épületet, így annak a telken való elhelyezése és mérete adott volt. Az oltártér a nyitott, látható és emberközeli egyház képének megfogalmazásaként a bejárathoz mind fizikailag, mind szimbolikusan közel került. A tömegalakításban a külső megjelenése hajó és bejárati torony elemekre tagolódik, ám a harangok valójában a két egység között vannak felfüggesztve. A tetősíkok változó dőlése, valamint a pengefalak égbetörő emelkedése mozgalmassá teszik a külsőt és a belsőt egyaránt. A homogén szürke

előtérből nagyítószerủen tárul fel az oltártér. A Tarnai István tervei szerint épült szegedi Szent Gellért római katolikus templom esetében pedig a többszörösen tört tetősíkok szolgálják a szentély rejtett, misztikus megvilágítását. A szeged-tarjánvárosi templomról részletesen: Rév 1987. 61-65.

${ }^{105}$ „A gyertyafény »szentebb « a villanyfénynél, a kö és a fa »szentebb « a müanyagnál. Ezért épp a szakrális épitészetben ügyelni kell arra, hogy ami új, ha mégoly merészen új és szokványokat tagadó is, legyen ugyanakkor elszántan és őszintén hagyományőrzö... A keresztény szakrális épitészetet egyébként is páratlan változatosság és megújulási készség jellemzi: ha valahol, hát itt bizonyára lehetséges az újitásnak és hagyományörzésnek ez a találékony és gazdag egymásba fonódása." Templomterek esztétikai kérdéseiröl: Tótfalusy 1977.

${ }^{106}$ Feltételezésünk szerint a nagy fesztávú rácsostartók alkalmazása a II. vatikáni zsinat hatására átalakuló liturgikus térhasználat megvalósítását kifejezetten segítette, és ugyanezen tendenciák a protestáns egyházak térhasználatát is megújították. Urbán-Vukoszávlyev 2016 b.


emlitett konzervativizmusa sem indokolja s mentheti. Az meg lehetetlen, hogy épp a templomépités terén görcsösen ragaszkodjunk a régi anyagokhoz és munkamódszerekhez. Sietve hozzá kell tennünk, hogy az új anyagok technikai lehetöségének ügyes fölhasználása csak akkor vezethet valódi megújuláshoz, ha az anyagi, formai mozzanatok mögé odazárkóznak a modern tartalmi igények." Tótfalusy 1977. 592.

${ }^{108}$ Prakfalvi 2003. 
beton födém béléstestekböl épült falak a föhomlokzat nyitott formálásának köszönhetően mégis közvetlenséget sugároznak. Az elöcsarnok tere elökészíti a templomtérbe való belépést, ahová az oltárral majdnem szemben érkezünk. A szentélynél a mennyezet felmagasodik, laterális fényt enged be a térbe, hogy aztán a végfalak felé haladva lesüllyedjen és a főhomlokzat felé ismét emelkedésnek induljon. A stiláris egységre való törekvés megmutatkozik a részletekben: a tervező nemcsak építésze, de építő mestere és képzőmüvésze is volt a templomnak. ${ }^{109}$

Bár Szabó István templomépítészeti munkásságának kétség kívül a legismertebb alkotása az imént említett Mindenszentek-templom, mégis szakrális építészetének sokkal egyedibb és újítóbb kezdeményezése a nagyfesztávú acél térrácsok alkalmazása, mely során a templomhajót az acélszerkezet belső burkolás nélkül határolja. ${ }^{110}$ A nagyfesztávú KIPSZER acél térrács szerkezeti lehetőségeinek köszönhetően az érdligeti Magyarok Nagyasszonya római katolikus templom (tervező: Szabó István; építés évei: 1978-1983) magastetőjének gerince épp a rövidebb oldallal fut párhuzamosan (9-10. ábra). A csendes udvar belső részén álló templom hosszanti oldala a fónézet, a bejárattal szembeni a szentély. A szimmetrikus főhomlokzat középső részét üvegfelületek teszik nyitottá. A szélső alacsonyabb terekben (részben az oldalkarzatok alatt) a kiszolgáló funkciók vannak. A belső tér összetettsége leginkább a kórusról átlátható: összefogott és kifejezetten dinamikus, a látványt uralja az acélszerkezet. A padló, valamint a szentély mögötti fekete-fehér-téglavörös falaknak az oltárasztalnál összefutó sugarai erős centrumot formálnak. A padok félkörívben e középpont köré rendezettek. A burkolat és az elrendezés miatt olyan, mintha az oltár felé
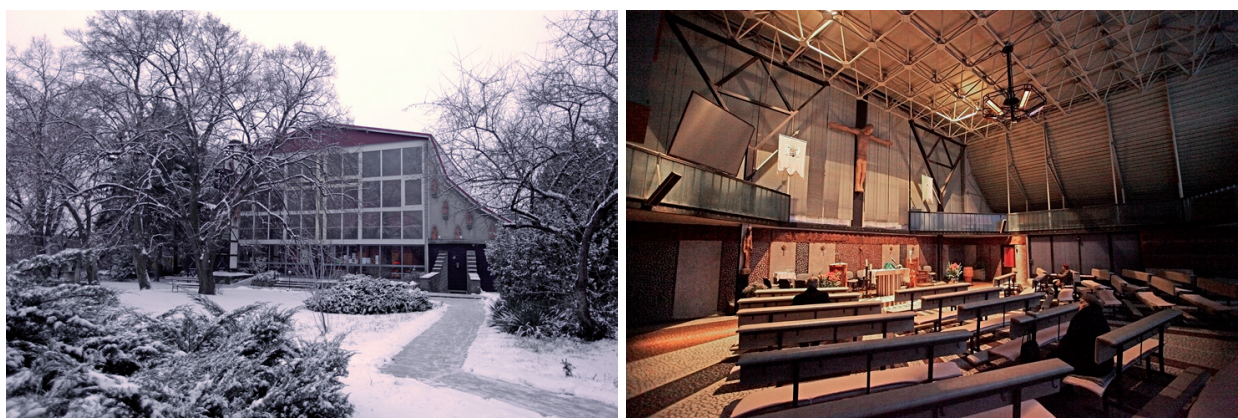

9-10. ábra. Érd-Érdliget, Magyarok Nagyasszonya római katolikus templom, 1978-1983. Építész: Szabó István (Fotó: Urbán Erzsébet, 2016)

\footnotetext{
${ }^{109} \mathrm{Az}$ egyik legismertebb modern katolikus templomot részletesen bemutatja: Hajnóczi-Emődy 1978, Vasadi 1977. 595-596 és Rév 1987. 52-57.

${ }^{110}$ Tervezői segédlet és katalógus a KIPSZER rendszerekhez: Beleznai. - Szabó István legkésőbbi, a budapest-vizafogói Tours-i Szent Márton és Flüe-i Szent Miklós római katolikus templománál (melyet már az építész tervezőtársa, Borsányi László fejezett be) a legutóbbi felújítás és átépítés során előkerült eredeti tervek és csomóponti részletek szerint már az acél térrácsra burkolópanelek kialakítását tervezte az építész - a burkolat elkészítése végül anyagi és kivitelezhetőségi okokból nem valósult meg, sőt az acél térrács helyett is síkfödém készült.
} 

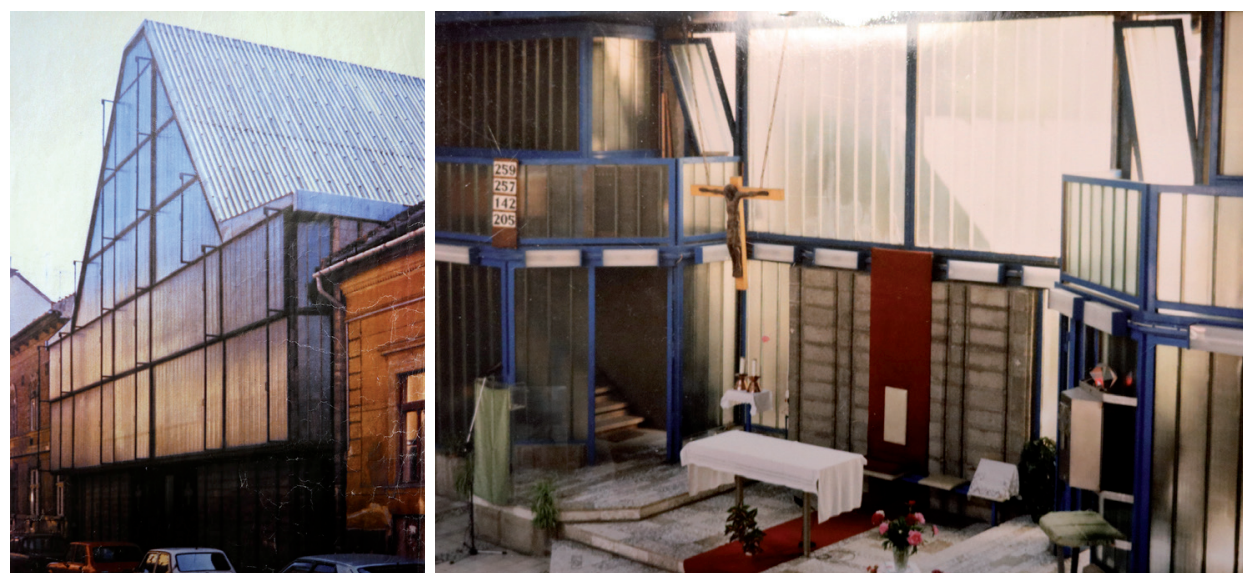

11-12. ábra. Budapest, Szent Kereszt római katolikus templom, 1976-1979. Építész: Szabó István, Borsányi László (Fotó: archív felvételek a templom Historia Domusából)

szűkülne, sủrüsödne a tér. Ez a templom kissé hủvösebb és nyugodtabb hangvételü a tervező korábbi munkáihoz képest.

A budapesti Szent Kereszt római katolikus templom (tervező: Szabó István, Borsányi László; építés évei: 1976-1979) az anyaghasználat terén még szokatlanabb, a legnagyobb öszinteséggel jellemezhető megoldásokkal készült (11-12. ábra). Homlokzata a földszinten a házak síkjába simul, az emeleti részen a karzattól konzolosan az utcaszint fölé kiugrik. Eredetileg a földszinti rész nyersbeton béléstestjei vakolatlanul, szabadon maradtak, a felső karzati homlokzatrész teljes felülete pallóüvegekből készült. ${ }^{111}$ A hagyományos nyeregtető ellenére a belsőben a KIPSZER térrács szerkezete dominál. ${ }^{112}$ Funkciójában komplex épület rejtőzik az egyszerünek tűnő térformálás mögött: a plébániához tartozó közösségi terek egy tömegbe épültek a templommal, a kettőt belső átrium udvar választja el egymástól. ${ }^{113}$

A korábbi példák mérnöki esztétikát alkalmazó sorából ugyan kiesik, mégis Szabó István építészetében is alkalomadtán megjelent - amennyiben a tervezési helyszín és

${ }^{111}$ Az épületről részletesen: Wesselényi-Garay 2010. 75-77. Az 1990-es években, majd 2001-ben a templomot átalakították, s ezek a külsőt és belsőt is érintő beavatkozások határozzák meg a mai megjelenést (pallóüvegek eltávolítása, téglaburkolatos falak kialakítása a szentélynél...). Urbán-Vukoszávlyev 2016 b.

${ }^{112}$ Szabó István másik temploma, az Ildikó téri református templom talán a legegyértelmübb hazai példája annak, amikor a szakrális térben a mérnöki szerkezet a teljes természetességét mutatja, mindennemü burkolat és díszítés nélkül. „Az Ildikó téri templom az ipari épületek - szerelőcsarnokok, raktárak, kiállitási helyiségek - épitésénél alkalmazott eszközök transzponálása szakrális épületre. Az épület térbehelyezése, idomainak merészsége, szokatlansága, csillagvizsgálóra emlékeztetö - tehát eleve felfelé orientáló - formája kétségtelenné teszi szakrális rendeltetését.” Rév 1987. 73-78. A Dunaújvárosi református templomban (tervező: Szabó István; építés évei: 1982-1985) szintén ugyanez a szerkezeti rendszer uralkodik a belső téren. Szabó István templomépítészeti tevékenységéhez kapcsolódóan: Koós 1991. 5.

${ }^{113}$ A belsőnek szerves része volt a tervező által készített képzőművészeti tárgyak sora, melyeket azonban rövid időn belül eltávolítottak helyükröl: az oltár fölötti üvegfelület elé függesztett alumínium szoborcsoport, a tetőszerkezet elemeiről lógó angyalokat megjelenítő plasztikák és a keresztút. 
lehetőségek úgy kívánták - a népies építészet formavilága. ${ }^{114} \mathrm{~A}$ környezeti kontextust tekintve a kis lakóházak és nyaralók magastetős tömegébe léptékében és formájában is szépen illeszkedik a terméskő és boronafalazatú Márkházán álló Krisztus király római katolikus templom (tervező: Szabó István; építés éve: 1979). ${ }^{115}$ A külső megjelenésben a helyi faanyagok használata dominál, felfedezhető az átértelmezett toronyelem, és a tömegképzést csupán a szokatlan módon egymásba metsző nyeregtetők teszik újszerüvé. ${ }^{116}$

Összességében megállapítható, hogy Szabó István templomainak legfeltűnőbb sajátossága az anyagválasztás és a formálás tekintetében is a szerkezetiség hangsúlyos vizuális jelenléte. Díszítésnélküliség, egyszerủ természetesség. Templomépítészetében sajátos alkotói arculatot alakított ki a KIPSZER térrács rendszerek alkalmazása. Munkásságának egyik legkésőbbi alkotásánál, a fertődi Szent Kereszt Felmagasztalása római katolikus templomnál (tervezö: Szabó István, Bán Ferenc, Bihary László, Asbóth Kristóf; építés évei: 1984-1986) ${ }^{117}$ a szerkezetet még inkább térbeli lefedéssé konstruálták a tervezők, így lehetőség nyílt rá, hogy már minden irányban megtörjék a szerkezetet. ${ }^{118}$

${ }^{114} \mathrm{~A}$ népi ihletésủ formavilág ebben a korszakban történő újrafelfedezésére talán leginkább jellemző példa a Szamoskéri református templom (tervezők: Bachmann Zoltán, Kistelegdi István, Csaba Gyula; építés évei: 1972-1975), melynek formálása Rév Ilona szerint a szecesszió 1970-es évekbeli újrafelfedezésének köszönhetö. Rév 1987. 60.

${ }^{115} \mathrm{Az}$ utca szintjétől néhány lépcsőfokkal megemelt Szent Imre római katolikus templom Mátraszentimrén (tervező: Németh Mária; építés éve: 1980) hasonló tervezői szempontok mentén épült. Dóczi Erika a fényben úszó oltártér kapcsán finnországi párhuzamokat említ, és Aarno Ruusuvuori 1961-ben épült hyvinkää-i épületét hozza példának: Dóczi 2008. 49. Szintén hasonló szerkezeti kialakítású a ruzsai Urunk színeváltozása római katolikus templom, mely 1985-87 között épült.

${ }^{116}$ Mégis fontos kiemelni a tradicionális anyaghasználattal és felületképzéssel feltünően kontrasztos vizuális élményt adó kortárs liturgikus mủvészeti tárgyakat, melyek szimbolikájával a - jellemzően falusi - kisközösségek nehezen tudtak azonosulni, így legtöbbször eltávolításra kerültek a templomtérből. Gondoljunk itt például Szabó István márkházai korpuszára, vagy éppen Csaba László művészeti alkotásaira. Mindazonáltal ezen egyház-, illetve liturgikus művészeti alkotások építészeti szempontból már csak azért is jelentősek voltak, mert a rurális szerkezeti hagyományokon alapuló tervezésmódban egyfajta drámai ellentpontként kívántak megjelenni, mely az épület kortárs mivoltát akarta jelölni. Egyházi és liturgikus müvészetről: Levárdy 1982.

${ }^{117}$ „A KIPSZER Tervezöiroda saját találmányként kidolgozott egy acél térrácsos szerkezetü térlefedést, ezzel a technológiával tervezte és kivitelezte föleg a Hungexpo kiállitási csarnokait, sík, kétdimenziós szerkezetre alkalmazva. A templom tervezésénél azonban továbbléptünk azzal, hogy kihasználtuk a még benne rejlö térbeli lehetöségeket, és kiterjesztettük három dimenzióra, minden irányban megtörve a szerkezetet. Akkoriban számitógépes tervezői programot még ritkán használtak hazánkban. A lefedö szerkezetet ezért modelleztük, amihez alaprajzot készitettünk, amelyen nyomon követhetök a térbeli lefedés által síkban megjelenö alaprajzi törések." Hartmann 2016. 62-64.

${ }^{118}$ Szabó István alkotói módszeréhez hasonlóan Bán Ferenc templomépítészetében is a célszerüség szándéka érhető tetten a tervezési folyamatban: „,Tóni (Plesz Antal) azzal kezdte - látva korábbi terveimet - felejtsem el, hogy rajzolni tudok. Elöbb szerkezetileg legyen rendben a ház, legyen müködöképes, aztán lehet formálni. „Puha« részekkel lehet kitölteni, amibe belemarkolhatsz, kitépsz belöle, hozzáadhatsz, mert elviseli. Ez volt az egészből a lényeg." Bodonyi 1986 és Bán 1986. - A Nyíregyháza Borbánya városrészében álló Szent László római katolikus templom (tervező: Bán Ferenc; építés éve: 1981-1982) családi házas övezetben épült. A sík területen álló templom mésztufa blokkból falazott, zsaluzást nem igénylö vasbeton szerkezettel, ragasztott fatartós térlefedéssel készült. Alaprajzilag a templomtér körcikk formára szervezett, mely a központ felé süllyedő 


\section{PERCZEL DÉNES}

A különleges belső térhatás érdekében történő egyedi tartószerkezetek alkalmazása nem feltétlenül jelentette azok belső térben való domináns megjelenését. ${ }^{19} \mathrm{~A}$ gyáli Szent István király római katolikus templom (tervező: Perczel Dénes; építés éve: 1983) tégla kitöltő falazattal, acél- és vasbeton vázzal épült. A plébániát és templomot is magába foglaló együttes bejárati része fölé ívesen nyúlik előre két pengefal, melyek harangtornyot formálnak. A szakrális tér nyolcszögletü, centrális alaprajzú, ehhez kapcsolódik a kórussal és bejárattal szemközti keresztelőkápolna. Az oltártér megvilágítása a ferde tetősík esésvonala mentén kialakított, hasítékszerú felülvilágítón keresztül történik, melynek egyenes vonalához csatlakozó, a nyolcszög alaprajzból következő háromszög tetősíkok intenzív hullámzást visznek. ${ }^{120}$

Az előbbi példától eltérően a közadakozásból felépült domaszéki Szent Kereszt római katolikus templom (tervező: Perczel Dénes; építés évei: 1985-1988) harangtornya mintha csak a tetőből nőne ki, kevésbé kapcsolódik szervesen az épület alsó részéhez, inkább additív elemként jelenik meg a kompozícióban. ${ }^{121} \mathrm{Az}$ oltár a bejárattal szemben található, eköré három oldalról néznek a padsorok erős centrális központot adva a szentélynek. Mind az ambó, mind az oltár szinte már a hívek között van elhelyezve, s ezt a szoros kapcsolatot tovább erősíti, hogy csak két lépcsőfokkal vannak a liturgikus berendezések kiemelve a templom járószintjétől.

Egészen más téri szituációt jelentettek a nagyobb léptékủ társasházi övezetekbe történő tervezési feladatok. Óbuda kis családi házait az 1970-es évek tömeges lakásépítési tervei elbontották, helyükön hatalmas panelházak nőttek ki a földből. A nagy urbanisztikai átalakításnak az ottani közösség temploma is útjában volt, elbontották, majd végül mégis ennek a helyén építették a ma álló új, Szentháromság római katolikus templomot (tervező: Perczel Dénes; építés évei: 1975-1984). A toronyelem jelentősége ebben a kontextusban már teljesen elveszíti korábbi szerepét, így a tervező más eszközökkel igyekszik kifejezni az épület szakrális karakterét (13-14. ábra). Az elsőre szokatlan főhomlokzat, bejárati kapuzat mögött egy alapvetően hagyományos

tetővel fedett. A geometrikus formákból építkező templom a posztmodern építészeti formák mellett hagyományos elemeket is tartalmaz: pillérekre támaszkodó portikusz félköríves záródású ablakokkal, illetve az íves falhoz illeszkedő hatoszlopos árkádsor. A templomhajó megvilágítását az ívesen végigfutó, sávszerü felülvilágító ablaksor adja. Bán Ferenc építészetéről: Szabó 2015. Az épületről bővebben: Rév 1987. 104, valamint Wesselényi-Garay 2010. 69-71.

${ }^{119}$ Míg a paksi Szentlélek római katolikus templomnál (tervező: Makovecz Imre; építés évei: 1988-1990) a szerkezet látható eleme a belsőnek, addig Perczel Dénes templomtereiben a tartószerkezet inkább a belsőben elérni kívánt mozgalmas térhatárolás síkfelületekkel burkolt háttérvázát jelenti. A paksi templomnál a látszó szelemenek és gerendák ugyan a szerkezetiség jelenlétét erősítenék a belső térben, azonban a roppant sürü díszítő-kiegészítő rátételemek miatt ezek vizuális szerepe hangsúlytalanná válik, és pusztán az épületbelső által elmesélni kívánt narratíva hátteréül szolgálnak. A paksi templom részletes ismertetését adja: Wesselényi-Garay 2010. 153, 158-161; Masznyik 1998; Csigó 2000; Fekete 1991 és Gerle 2002.

${ }^{120} \mathrm{Az}$ épületről részletesen: Rév 1987. 100-103.

${ }^{121}$ Távolról szemlélve Csaba László híressé vált, 1967-ben felépült hollóházi temploma juthat elsőre eszünkbe, azonban közelebb érve, ahogyan a teljes épület kirajzolódik, az összképen itt meghatározóbbá válik a hagyományos, már-már lakóházszerủ alsó tömeg kis bejárati fedett elöterével. 

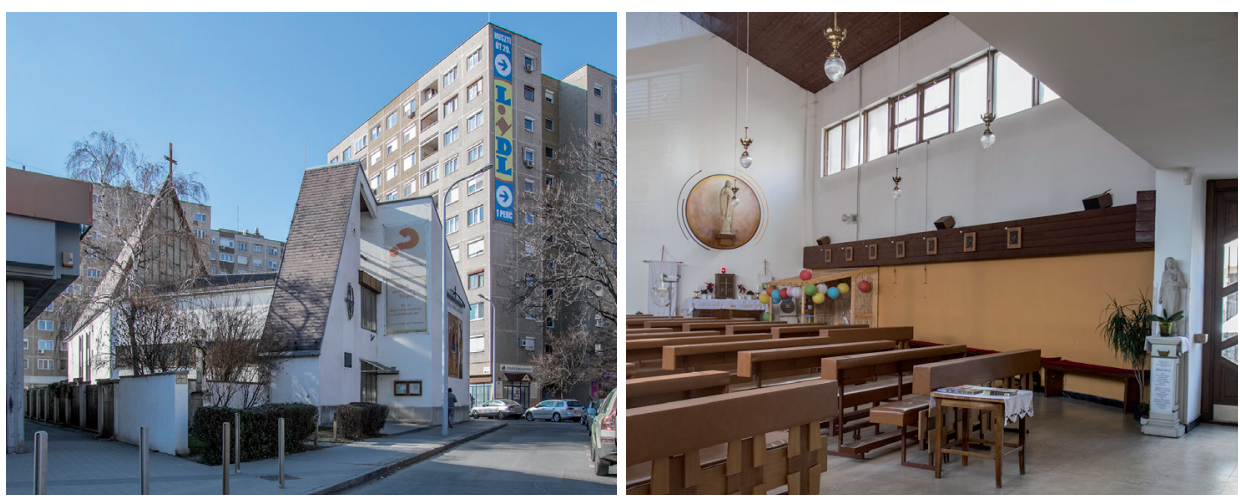

13-14. ábra. Budapest, Szentháromság római katolikus templom, 1975-1984. Építész: Perczel Dénes (Fotó: Urbán Erzsébet, 2019)

templomhajó található, ahol elsősorban a változatos hajlású tetősíkok által létrehozott fény-árnyék teszi mozgalmassá a térhatást.

A korszerübb épületszerkezeti rendszerek alkalmazása csak a rendelkezésre álló technikai háttér mértékéig történhetett - az építész nem támaszthatott a megvalósíthatótól magasabb elvárásokat. Ennek eredményeként Perczel Dénes templomainál a szerkezethasználat nem uralja a belső vizuális megjelenését, éppen csak annyira van hatással az esztétikai megjelenésre, hogy lehetővé tegye a hagyományos szerkezeti elemekkel nem kivitelezhető részletmegoldásokat.

\section{ÖSSZEFOGLALÓ ÉRTÉKELÉS}

Az építészeti tervezés értelmezés és újrafogalmazás. Ez különösen igaz a szakrális térre, valamint ennek a folyton változó korszellem szerinti fizikai megjelenítésére. ${ }^{122}$ A templomépítészet a definiálhatatlan tartalom végtelen lehetőségü formai leképezése. A korábbi történelmi időkben Isten jelenlétét távolinak és az általunk ismert világon kívülállónak, afelett állónak képzelték (melyet a magasba törő gótikus templomépítészet vagy az illuzionisztikus távlatokat nyitó barokk mennyezetfreskók értelmeztek építészeti formában). A körülöttünk lévő közvetlen és tágabb környezet megismerésének szélesedésével párhuzamosan Isten teológiai értelemben is ,,bekerült" az emberek közötti térbe, így a templomépítészetben is a korábbi végtelenbe való törekvés helyett a templom helyi, közösségi jellege kezdett erősödni. A templom egy ház a sok közül, a közösség háza. Elmondható, hogy a szocializmus utolsó évtizedeiben Magyarországon épített templomok szellemi és stiláris karakterei nem annyira a hazai folytonossággal, mint inkább a nemzetközi építészeti áramlatokkal hozha-

${ }^{122}$ „A templom tere ahhoz nyújt segitséget, hogy az ember oda belépve képes legyen túllépni a köznapi értelemben vett határain és átlépjen a megismerés egy egészen más szférájába. Ezt szolgálja a liturgia és az adott épitészeti tér.” Puhl 2016. 
tók párhuzamba. A II. vatikáni zsinat után felerősödő térkísérletek tapasztalatai jelentős szabadságot adtak a tervezőknek. A teológiai, liturgikus és építészeti változások csak lassan kerültek át az általános szakmai gyakorlatba, és Magyarországon sokkalta szerényebb és egyszerübb formában jelentek meg az új szerkezetek, építőanyagok, mint Észak-, illetve Nyugat-Európában. ${ }^{123}$ Ezt kompenzálták némiképp a tervezők koncepcionális térképző ötletei, az őszinte anyaghasználat, a néha takarékoskodásból adódó, elsőre meglepőnek tünő megoldások által létrejött egyedi alkotások. Az új, olykor formabontó épületeket nehéz volt a közösségekkel elfogadtatni. A hívők inkább a tradicionális tereket preferálták, így az új építészeti formákat gyakran komoly konfliktusok között fogadták.

Az egyház növekvő mozgástere ellenére, ${ }^{124}$ viszonylag kevés európai viszonylatban is kiugróan színvonalas templom épült a II. világháború és az 1989-es rendszerváltás között. A szakszerủ kivitelezési technológia hiánya és a korlátozott anyagi források okán sajnos ezek az épületek jellemzően alacsony szerkezeti minőséggel készültek. A szerkezetek természetes avulása, a növekvő komfortigények és az elöregedő gépészeti-elektromos rendszerek miatt napjainkra szükségessé vált ezen épületek modernizálása, ami gyakran együtt jár jelentős átalakításokkal is. Amíg Nyugat-Európában azért vált szükségessé a II. világháború utáni templomok átalakítása, mert a közösség létszáma jelentősen lecsökkent, és kihasználatlanná váltak az egyházi épületek, addig Kelet-Közép-Európa posztszocialista országaiban jellemzően még jelenleg is használatban vannak a korszakhoz köthető szakrális épületek.

A templomok sohasem voltak önmagukban létező, különálló épületek, mindig közösségi funkciók vették körbe őket. A korai modernizmustól kezdődően az építészek elkezdték kombinálni a közösségi és kiszolgáló funkciókat a templommal, és ez a folyamat az 1970-1980-as évekre felgyorsult. Összevetve a vizsgált templomokat, észrevehető a közösségi funkció és a templomtér egyre szorosabb kapcsolata. A funkciók közötti viszony ugyan idővel egyre szervesebbé vált, azonban a templomhajó és a közösségi terem közvetlen kapcsolata a római katolikus templomépítészet gyakorlatában nem terjedt el. Profán és szakrális funkciók egészítették ki egymást egy épületen belül, de a hierarchikus hangsúly mindig a liturgikus tereké maradt. A templomterek nyitottabbak lettek, az öncélú dekoráció eltűnt, és a belső tér homogénebbé és anyagszerübbé vált - gyakran szinte ipariasan puritán megjelenésủ lett. Az egyházés liturgikus müvészet jelentősége lassan növekedett: általános elvvé alakult, hogy a koncentráltan elhelyezett, egyszerủ mủvészeti alkotások - szinte csak jelzésértéküen megjelenítve - segítik leginkább az Istenre való koncentrációt. A művészeti alkotások $^{125}$ mellett a beáramló természetes fény komponálásának is fontosabb szerepe lett. Az építészeti térszervezés elsődleges meghatározó eleme az oltár elhelyezése volt. Az oltártér hangsúlyosságát és megvilágítási módját pedig döntően meghatározta a tetöforma és az itt kialakított bevilágító felület, jellemzően ez lett a belső tér legvilágosabb

${ }^{123}$ Schwarz 2007.

${ }^{124}$ Állam és egyház kapcsolatáról a közép-kelet-európai országokban 1945-1989 között: Nagy-Zombori 2014.

${ }^{125}$ Építészet és társművészetek kapcsolatáról: Nádor 2012. 
pontja. Az oltártér felé emelkedő vagy épp arra ereszkedő tetőforma a liturgikus centrum hangsúlyát adta, kialakítása lehetett sík lemezből vagy tört tetőformából is. Alaprajzi térkoncepció szerint hagyományos, sugaras, átlós és centrumképző elrendezések különültek el. A hagyományos hossztengelyes elrendezés, egyszerü ácsolt faszerkezetủ magastetôvel volt az általános és leginkább elfogadott. Mégis mivel fontos volt, hogy a miséző pap és a jelen lévő hívők között szorosabb kapcsolat jöhessen létre, így az építészek idővel igyekeztek a majdnem központos belső elrendezések mellett dönteni. Míg a korszak első szakaszában épült templomok jellemzően hoszszanti elrendezésúek voltak, addig az 1970-es évek közepétől már az átlós és sugaras elrendezés vált gyakoribbá. A centrumképző elrendezés a protestáns templomoknál a kapcsolódó közösségi funkciók révén jobban érvényesült. ${ }^{126}$

A templomépítkezés szinte kizárólag a közösség és a lelkész felelőssége volt, míg a meglévő múemléki templomok helyreállítását az állam anyagilag, szakmailag támogatta és felügyelte. Régi és új templomok egymással való viszonyában egyfajta kölcsönösség alakult ki: az újak a régiek hagyományait követve újították meg a formákat, a meglévők pedig a liturgikus terek átalakításai során a modern oltárt és térszemléletet vették át. Új templomok és környezetük kapcsolatát tekintve a korszak templomtervezői már nem igyekeztek olyan mértékben megkülönböztetni a templomot a környezetétől, mint korábban, gyakran maga a templom is csak egy ház lett a többi között. A korszakban épült egyedülálló templomok azonban mostanra elöregedtek, állandó és szakszerü karbantartásuk és megőrzésük szükséges volna, hiszen ezek is jelentős emlékei templomépítészeti örökségünknek. ${ }^{127}$

A korszak meghatározó templomépítészei Csaba László, Török Ferenc, Szabó István, később Perczel Dénes voltak. Mások jellemzően csak egy-két kiemelkedő alkotással járultak hozzá a hazai, II. világháború utáni szakrális építészethez. Az építőmüvészek életműveiben határozottan azonosíthatóak a szakrális építészet megvalósításáról való elképzelésükhöz illeszkedő szerkezetválasztási és anyaghasználati elvek. A komplexebb formaképzés vonatkozásában az egyre könnyebben hozzáférhető nemzetközi építészeti folyóiratoknak és szakkönyveknek, valamint a gyakoribbá váló tanulmányutaknak és kiutazásoknak köszönhetően a nyugat-európai és északi templomépítészet ekkortájt intenzívebben hatott a hazai szakrális építészetre is. Meghatározóak voltak a finnországi templomépítészeti formakísérletek, ${ }^{128}$ illetve a világszerte akkoriban terjedő brutalizmus nyers erejü épületeinek hatása. Ezzel szemben a kritikai regionalizmust pártolók inkább Dél-Európa (olaszországi és görögországi területek) és a Mediterráneum felé fordultak, a történeti épületek hagyomány által átörökíthető jelentőségeire koncentráltak. ${ }^{129}$

\footnotetext{
${ }^{126}$ Krähling-Nagy 2011.

${ }^{127}$ Épületek és tartószerkezetek rehabilitációjáról: Pattantyús-Ábrahám 2013.

${ }^{128} \mathrm{~A}$ korszak finnországi építészetét tanulmányutakat követő beszámolók révén az egyházi lapok olvasói is figyelemmel kísérték. Tiszta mérnöki-mủvészi elismeréssel ír az új finn templomépítészetről: József 1984.

${ }^{129}$ „,...úgy vélem, minden különbözöségük ellenére található bennük egy közös vonás, az épület születésének módja. A szükös anyagiak, a helyszinen található anyagok, szerkezetek, a rendelkezésre álló - változó mértékig szakképzett - munkaerö, és az épitész minden tényezöt figyelembe vevö együttmüködése alapján »ott« igy »kellett« vagy lehetett épiteni." Vajai 1985. 31.
} 


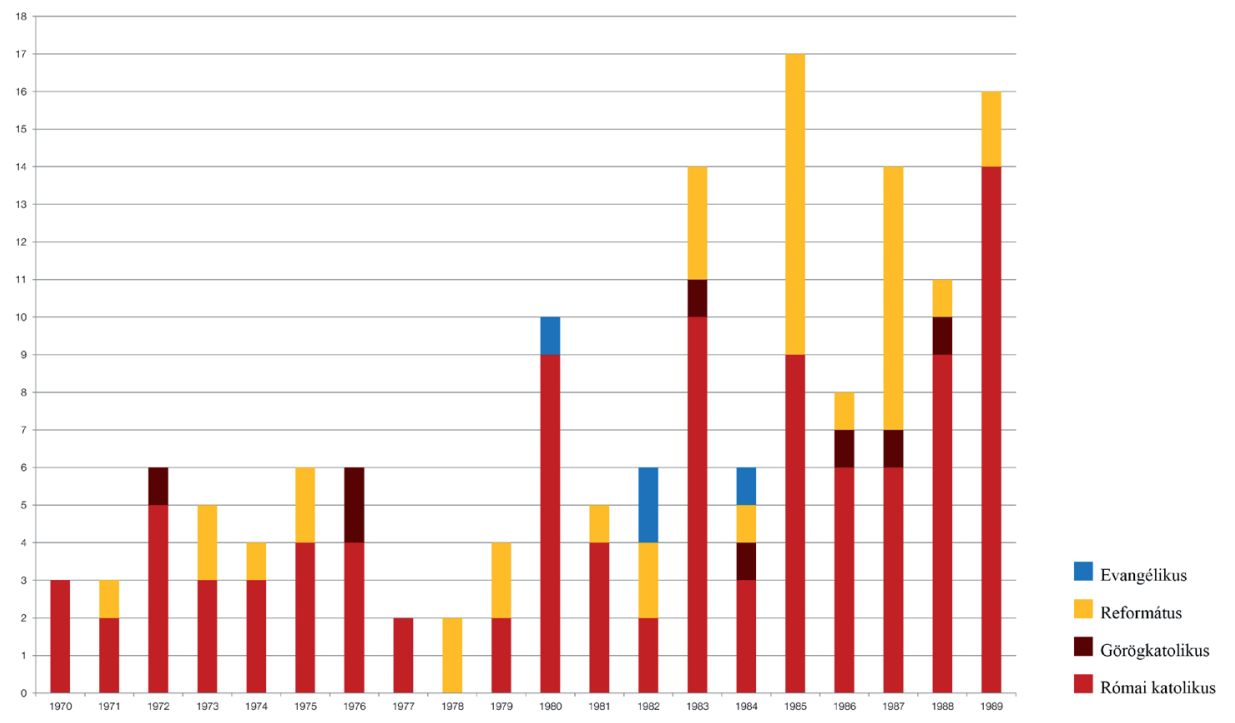

15. ábra. A tanulmányban számba vett 1970-1989 között épült magyarországi templomok felekezet szerinti megoszlásban (Diagram: Urbán Erzsébet, 2017)

A kutatás során az 1970-1989 között épült templomok közül 101 db római és $8 \mathrm{db}$ görögkatolikus, $36 \mathrm{db}$ református és $4 \mathrm{db}$ evangélikus templom került rendszerezésre és elemzésre (összesen $149 \mathrm{db}$ rekord) (15. ábra). Az adatok beszerzését levéltári források, nagyobb részben az illetékes plébániák feljegyzései és internetes honlapjaik helytörténeti leírásai segítették. Az épületek részletes építési körülményeiről és a közremüködő tervezők személyeiről kevés adat áll rendelkezésre, ebből fakadóan az építésre vonatkozó pontos évszámokat és a tervező személyét nem lehet minden esetben egyértelmüen meghatározni. A római katolikus templomok titulusai alapján jól látszódik, hogy a magyar szentek tisztelete továbbra is domináns maradt egészen a rendszerváltásig. A térképen is ábrázolt települések eloszlásából azonnal kitünik, hogy az Alföldön ebben a korszakban csekély számú templom épült (csakúgy, mint az 1945-1970 közötti időszakban), míg az Északi-középhegység és a Balaton környékén több kisebb településen is építkeztek a közösségek ${ }^{130}$ (16. ábra). Míg az 1970-es évek első felében évente csak 3-5 templom épült, addig az 1980-as években - nagyon ingadozó eloszlásban ugyan, de - már 9-10 templom építése valósult meg. A vizsgált két évtized folyamán legnagyobb számban római katolikus templomok épültek, református templomok föként a korszak második felében, míg evangélikus templomok csak időben elszórtan jöttek létre. A megerősödő Magyar

\footnotetext{
${ }^{130}$ Ennek oka egyrészt a turizmus, másrészt az Alföldet jellemző tsz-esítés, tagosítás, ami nagy területekre vonatkozóan hozott létre új településközpontokat, ami ugyanakkor darabszámban természetesen jóval kevesebb számú templomot is eredményezett.
} 


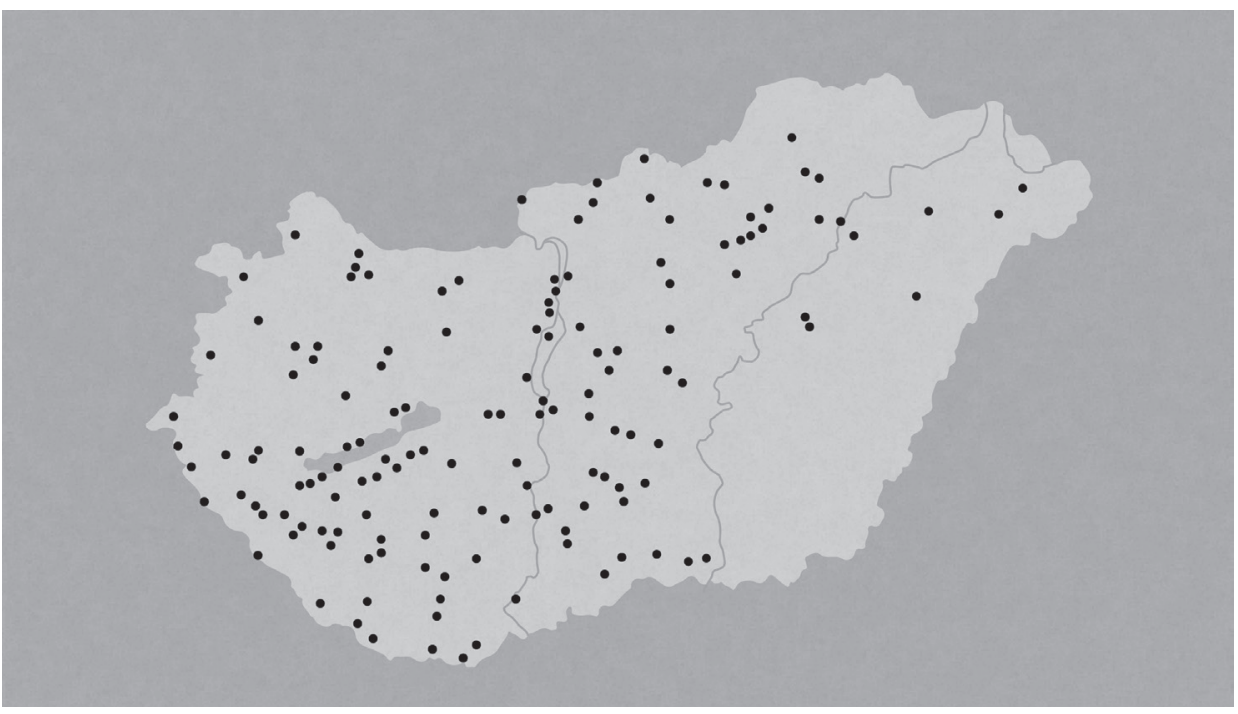

16. ábra. A tanulmányban számba vett 1970-1989 között épült magyarországi templomok (Térképes ábrázolás: Urbán Erzsébet, 2017)

Görögkatolikus Egyház pasztorációjának köszönhetően a görögkatolikus gyülekezetek templomai elsősorban Észak- és Északkelet-Magyarországon épültek az 1980-as évek közepén.

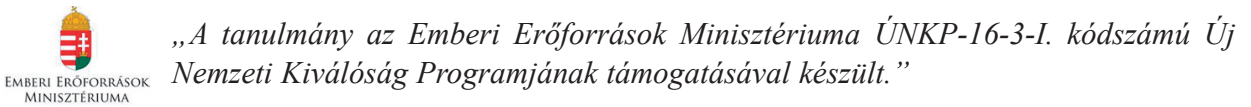

\section{IRODALOM}

A liturgikus berendezési tárgyak és eszközök müvészete. 1968. Országos Egyházművészeti és Mủemléki Tanács.

A II. Vatikáni Zsinat dokumentumai. Szent István Társulat, Budapest 2007.

Adriányi Gábor: A Vatikán keleti politikája és Magyarország 1939-1978. A Mindszenty-ügy. Kairosz, Györ 2001a.

Adriányi Gábor: Az egyháztörténet kézikönyve. Szent István Társulat, Budapest $2001 b$.

Albertini Péter - Bacsóka Béla - Balássy László - Békési Sándor: Keresztény ember a szocialista társadalomban. Ecclesia Könyvkiadó, Budapest 1977.

Ali István: Az egyház és a technikai újdonságok. Vigilia 35 (1970) 6. 377-379.

Andrási Gábor: „Forma és struktúra”. Vigilia 45 (1980) 12. 861-863.

Arató Miklós: Templomaink liturgikus tere. In: Teológiai évkönyv 1975. Szerk.: Cserháti József Keszthelyi Ferenc - Nyíri Tamás. Szent István Társulat, Budapest 1975.

Baku, Eszter - Urbán, Erzsébet - Vukoszávlyev, Zorán: Modern Church Architecture in Hungary. Research Plan on Re-examination of Changing Tendencies of the 20th-Century Church Architecture of the Roman Catholic Church. Architectura Hungariae 16 (2017) 4. 133-144. 
Balogh Ferenc: Vallási ismeretek, szakrális terek. Kereskedelmi és Idegenforgalmi Továbbképző, Budapest 2004.

Balogh Margit - Gergely Jenő: Állam, egyházak, vallásgyakorlás Magyarországon, 1790-2005. I. História-MTA Történettudományi Intézete, Budapest 2005.

Bán Ferenc: Szerkesztőségi beszélgetés Bán Ferenc építésszel. Magyar Épittőmüvészet (1986) 4. 27.

Bangó Jenő: Urbanizmus és teológia. Vigilia 35 (1970) 7. 443-446.

Beke László: Lehet-e építészeti tendenciákról beszélni? Magyar Épitömüvészet (1984) 1. 13-15.

Beleznai Károlyné (szerk.): KIPSZER katalógus. Térrácsos csarnok épitési rendszer katalógusa. Könnyüipari Szerelő és Építő Vállalat, Budapest.

Bíró Imre: Harminc esztendő a párbeszéd útján. Vigilia 45 (1980) 10. 665-668.

Boda László: Egyházmúvészeti szempontok a zsinat után. Vigilia 37 (1972) 2. 78-84.

Bodonyi Csaba: Szubjektív bevezetés Bán Ferenc terveihez. Magyar Épitömüvészet (1986) 4. 21.

Bouyer, Louis: Épitészet és liturgia. Agapé, Szeged 2000.

Bozsóky Pál Gerő - Lukács László: Az elnyomatásból a szabadságba. Vigilia, Budapest 2005.

Csaba Eszter: Csaba László 90 - visszatekintés az építész szakrális életmüvére. Épitészfórum. http:// epiteszforum.hu/csaba-laszlo-90-visszatekintes-az-epitesz-szakralis-eletmuvere (Utolsó megtekintés: 2014. 02. 16.)

Csaba László: Róm. kat. templom Hodász nagyközségben. Magyar Épitőmüvészet (1978) 3. 40-43.

Csaba László: Templomok és templomszerkezetek. Magyar Épitőipar 39 (1990) 5. 193-200.

Cserháti József: Tovább a nyitott utakon. Vigilia 45 (1980) 10. 651-659.

Cserháti József - Esze Tamás (szerk.): Egyházi épületek és mütárgyak gondozása. Képzőművészeti Alap Kiadó Vállalata, Budapest 1971.

Csete György: Csete György és Dulánszky Jenö. Architectura Vallomások. Kijárat Kiadó, Budapest 2001.

Csete György - Gerle János - Szegő György - Janáky György: Három vélemény építészetünk tendenciáiról. Magyar Épitömüvészet (1984) 1. 10-12.

Csigó László: Magyar katolikus templomok. Anno, Budapest 2000. 46-47.

Diós István - Viczián János (szerk.): Magyar Katolikus Lexikon I-XV. Szent István Társulat, Budapest 1993-2010.

Dóczi Erika: „Míg kövekből templomot emelnek, kövekként maguk is templommá épüljenek...”Szakrális építészet Magyarországon 1945-1989. Utóirat - Post Scriptum 8 (2008) 5. 47-51.

Doromby Károly: A Vigilia negyven éve. A felszabadulás utáni évtizedek. Vigilia 40 (1975) 4. 229-235.

Fekete György: Római katolikus templom, Paks. Építész Makovecz Imre. Magyar Épitömüvészet LXXXII (1991) 4. 8-12.

Ferkai András: Kell-e építészeti tendenciákról beszélni? Magyar Építőmüvészet (1984) 1. 16-17.

Ferkai András: Negyven év magyar építészete. Magyar Épitőmüvészet (1985) 2. 22-27.

Ferkai András: Építészet a második világháború után. In: Magyarország épitészetének története. Szerk.: Sisa József - Dora Wiebenson. Vince Kiadó, Budapest 1998. 305-329.

Friedman, Donald: Historical Building Construction: Design, Materials, and Technology (Second Edition). W. W. Norton, New York 2010.

Gadányi Jenő: Három probléma: tér, forma, szín. (Gadányi Jenő Feljegyzéseiből.) Vigilia 43 (1978) 5. 326-330.

Garai Gréta: A közösség centrumában - Magyar katolikus templomépitészet 1970-1986 között. TDK dolgozat. Budapesti Műszaki és Gazdaságtudományi Egyetem, Építészmérnöki Kar, Budapest 2015 .

Garai, Gréta - Vukoszávlyev, Zorán: Supreme Pastor of the Church Cares for the Hungarian Church. Church Architecture of the Hungarian Church During the First Decade of John Paul II's Papacy. Periodica Polytechnica Architecture 48 (2017) 1. 53-57.

Garai Gréta - Zsembery Ákos: Négy templom, négy képlet - Török Ferenc templomépítészetének jelentősége a '70-es évek hazai templomépítészetében. Architectura Hungariae XVI (2017) 1. 7-19.

Gergely Jenő: A katolikus egyház Magyarországon 1944-1971. Kossuth, Budapest 1985. 
Gerle János: Makovecz Imre. Serdián, Budapest 2002. 158-164.

Gilyén Nándor: Szerkezet és forma az épitészetben. Műszaki Könyvkiadó, Budapest 1982.

Guzsik Tamás: Szakrális terek funkcióelemzése. Egyetemi Jegyzet. I-III. Budapest 1988.

Hajnóczi Gábor - Emődy Attila: A farkasréti „Mindszentek” temploma, Budapest. Építész: Szabó István. Magyar Épitömüvészet (1978) 3. 44-47.

Hajós-Baku Eszter: Hagyomány és újitás. A centralitás történeti hagyománya és korszerüsége a két világháború közötti magyar templomépitészetben. Doktori értekezés. Budapesti Műszaki és Gazdaságtudományi Egyetem, Építészmérnöki Kar, Csonka Pál Doktori Iskola, 2018.

Hartmann Gergely (szerk.): Templomaink tegnap és ma: Győr-Moson Sopron megye templomépitészete, 1897-2014. Győr-Moson-Sopron Megyei Építész Kamara, Györ 2016.

Horváth Z. Kálmán - Csernoch Miklós: A térlefedőrendszerek általános rendszere. Magyar Épitömüvészet (1970) 6. 59.

Jäger, Frank Peter (szerk.): Old and New. Design Manual for Revitalizing Existing Buildings. Birkhauser, Basel 2012.

Janáky István: A mai magyarországi építészet stíluskérdései. Magyar Építőmüvészet (1984) 1. 18-21.

József Dénes: Finnországi emlékek - Épületekről, építészetről. Vigilia 14 (1984) 2. 94-96.

Kathy Imre: Építészeti fényképpályázat 1976. ‘Tornyok városon és falun.’ Magyar Épitőmüvészet (1977) 5. 60-63.

Katona Vilmos: Az irányított-tengelyes szerkesztés kortárs reneszánsza Európa katolikus templomépítészetében. Magyar Egyházzene XXI (2014) 4. 403-414.

Katona Vilmos: A csend mint építészeti térkoncepció: Kontemplatív terek napjaink templomépítészetében - I. Utóirat. A Régi-Új Magyar Épitómüvészet melléklete 16 (2016) 86. 74-78.

Katona, Vilmos: The Spatial Dimension of Liturgy: Historical and Contemporary Accounts of Communio-Space in Europe's Latin Rite Liturgical Architecture. Épités - Épitészettudomány 45 (2017) 1-2. 173-213.

Katona, Vilmos - Vukoszávlyev, Zorán: Modern Tradition and Liturgy: The Ways of Modernism in Hungarian Church Architecture in 20th Century. Architektúra \& Urbanizmus 66 (2012) 1-2. 2-23.

Kerekrétyová, Jana: Christian Believers in Socialist Slovakia 1969-1989. Privatizing and Deprivatizing Religion. Central European University 2015.

Kisasszondy Éva (szerk.): Az Állami Egyházügyi Hivatal iratanyagának jegyzékei I. Adattár. Magyar Országos Levéltár, Budapest 2005.

Kleineisel János: Társadalmunk, fizikai környezetünk problémái. Magyar Épitöművészet 77 (1986) 4. $41-42$.

Koós Judith: A magyarországi református templomok stílusváltozásai. Magyar Épitőmüvészet 82 (1991) 4. 4-5.

Köbel Szilvia: Oszd meg és uralkodj! - Az állam és az egyházak politikai, jogi és igazgatási kapcsolatai Magyarországon 1945-1989 között. Rejtjel, Budapest 2005.

Köpeczi Bócz Edit: Az Állami Egyházügyi Hivatal tevékenysége. Akadémiai Kiadó, Budapest 2004.

Körner, Hans - Wiener, Jürgen (szerk.): »Liturgie als Bauherr«? Moderne Sakralarchitektur und ihre Ausstattung zwischen Funktion und Form. Klartext Verlag, Essen 2010.

Kránitz Mihály: A II. Vatikáni Zsinat dokumentumai negyven év távlatából. Szent István Társulat, Budapest 2002.

Krähling, János - Nagy, Gergely Domonkos: Church as a Home - Sacral and Profane Functions in Modern Hungarian Churches. Periodica Polytechnica Architecture 42 (2011) 1. 33-41.

Lantos Edit: Három-négy egyszerủ pasztellszín. - A II. Vatikáni Zsinat liturgikus rendelkezéseinek hatása a templomokra és a templomba járókra. Utóirat - Post Scriptum 8 (2008) 5. 42-46.

Lantos Edit: Logikai készlet. Új építésű római katolikus templomok (1960-1970). Ars Hungarica 44 (2018) 2. 135-164.

Lékai László: Három évtized. Vigilia 45 (1980) 10. 649-650.

Levárdy Ferenc: Magyar templomok müvészete. Szent István Társulat, Budapest 1982.

Lukács László: A Vigilia beszélgetése Csaba László építésszel. Vigilia 54 (1989) 1. 49-59. 
Magyar Országos Levéltár iratanyaga: MOL-XIX-A-21-e-0010-1/1975; MOL-XIX-A-21-d-0010-4/1977.

Masznyik Csaba: Mai templomok a történeti templomépítés és térszervezés tükrében. Alaprajz (1998) 5. 33-35.

Meggyesi Tamás: A szakrális tér és a fény. Vigilia 78 (2013) 5. 322-329.

Merényi Ferenc: A magyar épitészet 1867-1967. Müszaki Könyvkiadó, Budapest 1970.

Miklós Imre: Harminc esztendővel a megállapodás után. Vigilia 45 (1980) 10. 660-665.

Moravánszky Ákos: Tendenciák újabb építészetünkben. Magyar Épitömüvészet (1984) 1. 22-33.

Müller, Tim - Neundorf, Anja: The Role of the State in the Repression and Revival of Religiosity in Central Eastern Europe. Social Forces 91 (2012) 2. 559-582.

Nádor Edina: Épitészet és társmüvészetek kapcsolódásának területei. Doktori értekezés. Pécsi Tudományegyetem Pollack Mihály Müszaki és Informatikai Kar, Breuer Marcell Doktori Iskola, 2012.

Nagy Mihály Zoltán - Zombori István (szerk.): Allam és egyház kapcsolata Kelet-Közép-Európában 1945-1989 között. - Intézmények és módszerek. METEM Historia Ecclesiastica Hungarica Alapítvány, Budapest 2014.

Nagy Zoltán: Gondolatok a térszervezésröl. Magyar Épitőmüvészet (1972) 1. 60-63.

Nagymihályi Géza: A keleti templom és a közösségi misztika. Vigilia 42 (1977) 9. 600-602.

Napló. Kádár János a szövetségi politikáról, az állam és az egyház viszonyáról. Vigilia 45 (1980) 6. 417.

Nyíri Tamás: Szekularizáció és transzcendencia. Vigilia 35 (1970) 5. 291-298.

Pallister, James: Sacred Spaces: Contemporary Religious Architecture. Phaidon Press, London 2015.

Pattantyús-Ábrahám Ádám: Épületrehabilitáció. Tartószerkezetek helyreállitása, átépitése és megerösitése. Terc, Budapest 2013.

Pogány Frigyes: Lépték a városépítészetben. Magyar Építőmüvészet (1976) 1. 54-57.

Pollack, Detlef: Religiousness Inside and Outside the Church in Selected Post-communist Countries of Central and Eastern Europe. Social Compass 50 (2013) 3. 321-334.

Prakfalvi Endre: Római katolikus templomok az egyesitett fövárosban. Budapest Főváros Önkormányzata, Budapest 2003.

Puhl Antal: A kopernikuszi fordulat Török Ferenc templom-építészetében. Épitészfórum. http:// epiteszforum.hu/a-kopernikuszi-fordulat-torok-ferenc-templom-epiteszeteben (Utolsó megtekintés: 2018. 02. 16.)

Puskás Attila - Perendy László: A II. Vatikáni Zsinat: Isten ajándéka az egyház és a világ számára. Szent István Társulat, Budapest 2013.

Rév Ilona: A templom korunk építészetében. Vigilia 49 (1984) 2. 82-85.

Rév Ilona: Templomépitészetünk ma. Corvina, Budapest 1987.

Romsics Ignác: Magyarország története a XX. században. Osiris, Budapest 2010.

Santarcangeli, Paolo: A torony. Vigilia 49 (1984) 2. 107-109.

Schwarz, Rudolf: Kirchenbau. Welt vor der Schwelle. Schnell+Steiner, Regensburg 2007.

Seregi György: Acél épületszerkezetek. Gyorsjelentés Kiadó, Budapest 1995.

Seregi György: Acélvázas csarnokok. Terc, Budapest 2001.

Seregi György (szerk.): Fémszerkezetek évkönyv 2002. Terc, Budapest 2002.

Simon Mariann: Minták és módszerek - A hetvenes évek hazai építészete és a karakter. Épités Építészettudomány 29 (2001) 3-4. 347-360.

Somorjai Ádám: Mindszenty József és az esztergomi érseki szék üressé nyilvánításának dátuma. Magyar Sion. Új folyam I. XLIII (2007) 1. 99-109.

Stan, Lavinia - Turcescu, Lucian: Church and State under Real Socialism. In: Les doctrines internationalistes durant les années du communisme réel en Europe - Internationlist doctrines during the years of real communism in Europe. Szerk.: Iulia Motoc - Emmanuelle Tourme-Jouannet. 2012. 75-96.

Stock, Wolfgang Jean: Europäischer Kirchenbau 1950-2000 - European Church Architecture. Prestel, München 2002. 
Stock, Wolfgang Jean: Europäischer Kirchenbau 1900-1950 - European Church Architecture. Prestel Verlag, München 2006.

Szabó Levente: Bán Ferenc épitészete - The Architecture of Ferenc Bán. Terc, Budapest 2015.

Szendröi Jenő (szerk.) Ipari épitészetünk. Müszaki Kiadó, Budapest 1965.

Szendrői Jenő (szerk.) Magyar épitészet 1945-70. Corvina, Budapest 1972.

Szigeti Endre: Az egyház és az állam jogviszonyának történeti háttere. Vigilia 38 (1973) 6. 373-381.

Szigeti Kilián: Az új miserendről. Vigilia 35 (1970) 2. 76-83.

Tordai Zádor: Templom és szertartás. Vigilia 14 (1984) 2. 97-101.

Tótfalusy István: A szakrális tér esztétikájához. Vigilia 42 (1977) 9. 586-595.

Török Ferenc: Múlt és jelen. Magyar Épitömüvészet (1985a) 1. 31.

Török Ferenc: Római katolikus templom, Balatonfenyves. Magyar Építőmüvészet (1985b) 1. 36-37.

Török Ferenc: Római katolikus templom, Révfülöp. Magyar Epitömüvészet (1985c) 1. 34-35.

Török Ferenc: Épület és helyszín. Magyar Épitőmüvészet (1986) 4. 20.

Török Ferenc: Török Ferenc (Vallomások - Architectura). Kijárat Kiadó, Budapest 1996.

Török Ferenc: A szakrális tér. A modern templomépítészet Magyarországon. Vigilia 78 (2013) 5. 330 336.

Török Ferenc - Török Ferencné (szerk.): Épitészet és hitvallás életmükiállítás. Magyar Mủvészeti Akadémia, Budapest 2016.

Turányi László (szerk.): Magyar Katolikus Almanach II. Apostoli Szentszék Könyvkiadója, Budapest 1988.

Urbán Erzsébet - Vukoszávlyev Zorán: Árkay Bertalan templomépítészete a második világháború után. Architectura Hungariae 15 (2016a) 1. 7-42.

Urbán, Erzsébet - Vukoszávlyev, Zorán: Resistance to Oppression: Case Study of the Hungarian Catholic Church Architecture 1945-1989. In: 14th International DoCoMoMo Conference: Adaptive Reuse. Szerk.: Ana Tostões - Zara Ferreira. DoCoMoMo International - Casa da Arquitectura, Lisbon 2016b. 576-581.

Vajai Tamás: Török Ferenc templomaihoz. Magyar Épitömüvészet (1985) 1. 31.

Vákár Tibor: Templomépítés és környezet. Magyar Épitöművészet (1982) 3. 60-63.

Vasadi Péter: Öt templom - öt tér. Vigilia 42 (1977) 9. 595-600.

Vukoszávlyev Zorán: Tisztább képletek. A kortárs szakrális építészet Magyarországon. / Clearer Formulas. Contemporary Sacred Architecture in Hungary. In: A Mindenség Modellje. Kortárs Magyar Templomépitészet / Model of the Universe. Szerk.: Wesselényi-Garay Andor. Contemporary Hungaryian Church Architecture. Modem, Debrecen 2010. 17-24.

Vukoszávlyev Zorán: Anyag és csend. Épités - Épitészettudomány 39 (2011) 3-4. 243-255.

Vukoszávlyev, Zorán: Materiality Shaping Immateriality - Immanence and Transcendence in Contemporary Hungarian Church Architecture. In: Architettura e liturgia - Autonomia e norma nel progetto. Szerk.: Andrea Longhi. Bononia University Press, Bologna 2017. 105-115.

Vukoszávlyev Zorán - Garai Gréta: Minták és képek: Beszélgetés a 80 éves Török Ferenccel az 1970-es évek hazai templomépítészetéröl. Utóirat: A Régi-Új Magyar Épitömüvészet Melléklete XVII (2017) 92. 57-60.

Vukoszávlyev Zorán - Urbán Erzsébet: Magyarország templomépítészete 1945-1964 között. Vázlat az alkotómüvészi értékeléssel megállapítható építészeti folytonosságról. Épités - Épitészettudomány 44 (2016) 3-4. 247-315.

Wesselényi-Garay Andor (szerk.): A mindenség modellje / Model of the Universe. Kortárs magyar templomépitészet / Contemporary Hungarian Church Architecture (2. kiadás). Modem, Debrecen 2010. 


\title{
CHURCH ARCHITECTURE AND SOCIALISM
}

\author{
RELATIONS OF THE STRUCTURE, FORM AND CONTENT IN THE \\ HUNGARIAN \\ CHURCH ARCHITECTURE IN THE 1970-1980S
}

\begin{abstract}
Summary
Intensive church construction activity of the Hungarian Christian churches stopped fundamentally, because of the secularization that came with the political takeover after WWII. The style and forming techniques of the churches built in the interwar period could be perceptible for almost two decades, but from the early 1960s new form experimentations have begun, and style pluralism has widened from the 1970s, thanks to the impulse of Vatican Council II. New, in the field of church architecture formerly not used building structures and materials appeared beside the traditional ones (which often gave an industrial, almost profane appearance to the sacral space). Churches in the period were built under the simplest circumstances - with the easiest obtainable building materials and with the help from the local communities -, thus there is not really an opportunity to analyse complex structural systems and joints, so this study aims to group the buildings according to the visual-aesthetic appearance and accent of the structures. The research took into account a much larger building stock than mentioned in previous literature. Although most of these churches do not own outstanding architectural value, still their numerical value and their construction itself are important from a sociological, church historical perspective. The churches enumerated in the article are intentionally not cited in chronological order. After the analysis of these buildings, it is clear that the traditional longitudinal arrangement with the conventional brick masonry and timber roof structure is dominant in the first third of the period. Later mainly monolith reinforced concrete frame structures with infill brickwork, or freely formed structural systems with reinforced concrete slabs were designed. Traditional building materials and structures come to the fore with the spread of the postmodern and the rediscovery of the elements of historicism in the last stage of the examined period.
\end{abstract}

Keywords: church architecture, Vatican Council II, liturgical reform, building structures, architectural form and content

Open Access nyilatkozat: A cikk a Creative Commons Attribution 4.0 International License (https://creativecommons.org/licenses/by/4.0) feltételei szerint publikált Open Access közlemény, melynek szellemében a cikk bármilyen médiumban szabadon felhasználható, megosztható és újraközölhető, feltéve, hogy az eredeti szerző és a közlés helye, illetve a CC License linkje és az esetlegesen végrehajtott módosítások feltüntetésre kerülnek. (SID_1)

Beérkezett: 2018. február 20. Elfogadva: 2018. június 4.

Online First megjelenése: 2019. június 7. 
